Prepared in cooperation with the U.S. Department of the Army

\title{
Summary of Hydrologic Testing of the Floridan Aquifer System at Hunter Army Airfield, Chatham County, Georgia
}
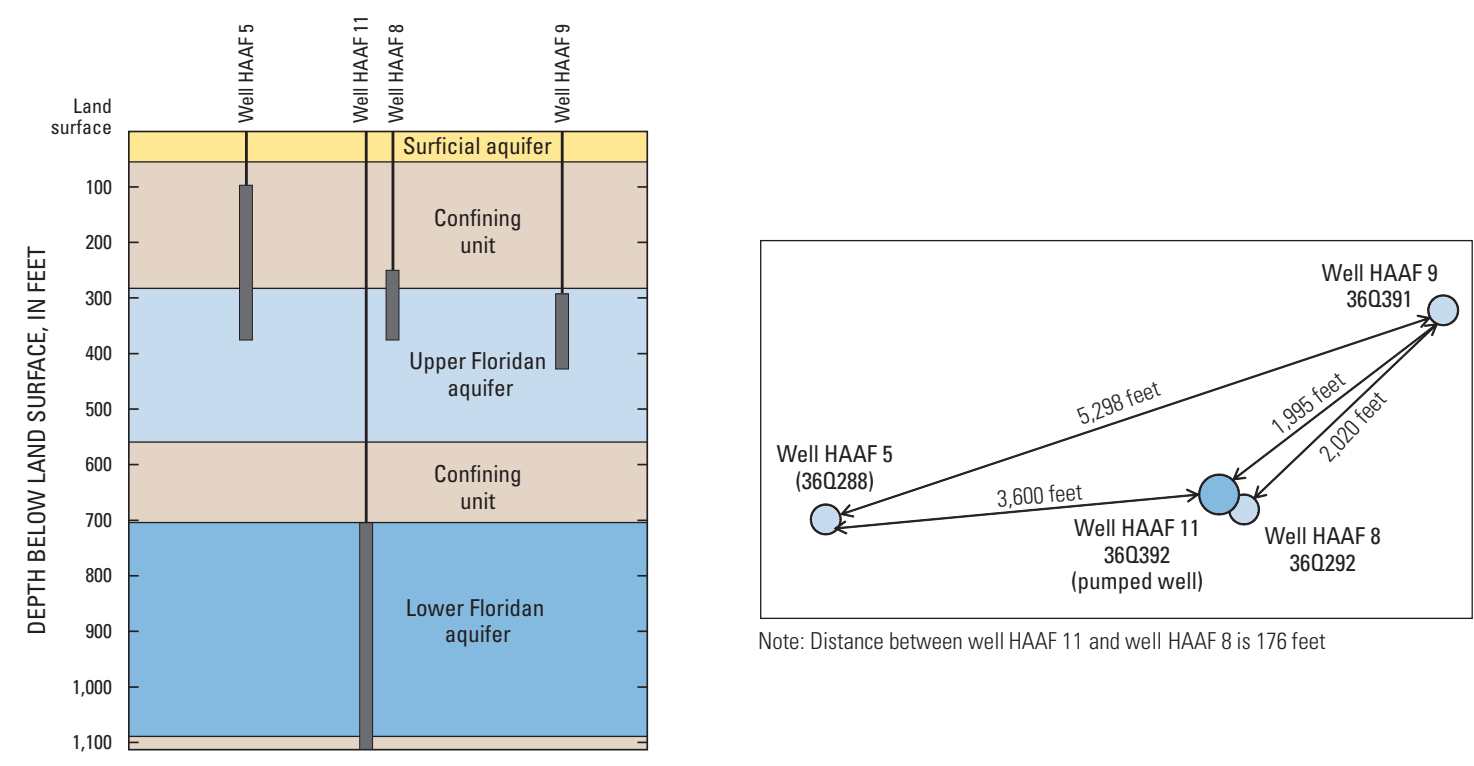

Note: Distance between well HAAF 11 and well HAAF 8 is 176 feet
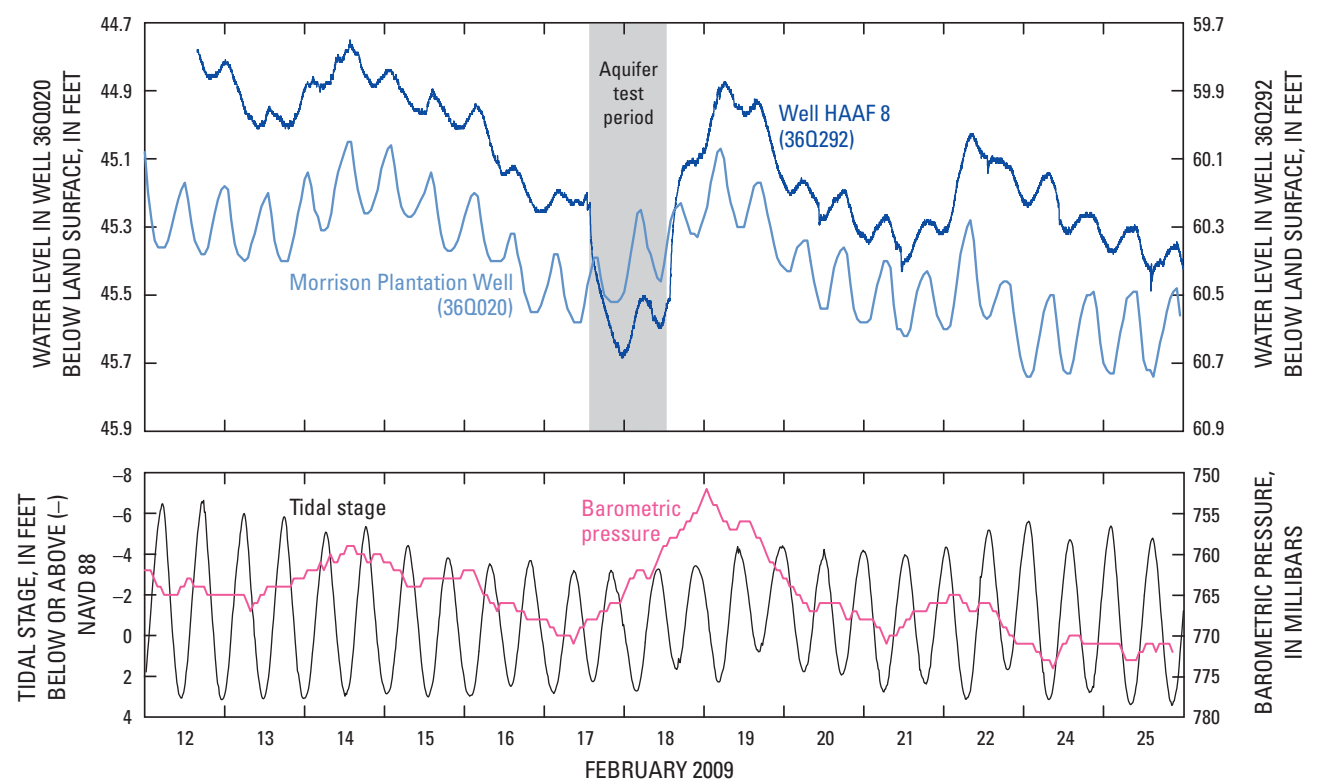

Open-File Report 2010-1066

U.S. Department of the Interior

U.S. Geological Survey 
Cover. See figures 11 and 13 of this report. 


\section{Summary of Hydrologic Testing of the Floridan Aquifer System at Hunter Army Airfield, Chatham County, Georgia}

By Lester J. Williams

Prepared in cooperation with the U.S. Department of the Army

Open-File Report 2010-1066 


\title{
U.S. Department of the Interior \\ KEN SALAZAR, Secretary \\ U.S. Geological Survey \\ Marcia K. McNutt, Director
}

\section{U.S. Geological Survey, Reston, Virginia: 2010}

\author{
For more information on the USGS — the Federal source for science about the Earth, its natural and living resources, \\ natural hazards, and the environment, visit http://Www.usgs.gov or call 1-888-ASK-USGS \\ For an overview of USGS information products, including maps, imagery, and publications, \\ visit http://www.usgs.gov/pubprod \\ To order this and other USGS information products, visit http://store.usgs.gov
}

Any use of trade, product, or firm names is for descriptive purposes only and does not imply endorsement by the U.S. Government.

Although this report is in the public domain, permission must be secured from the individual copyright owners to reproduce any copyrighted materials contained within this report. 


\section{Contents}

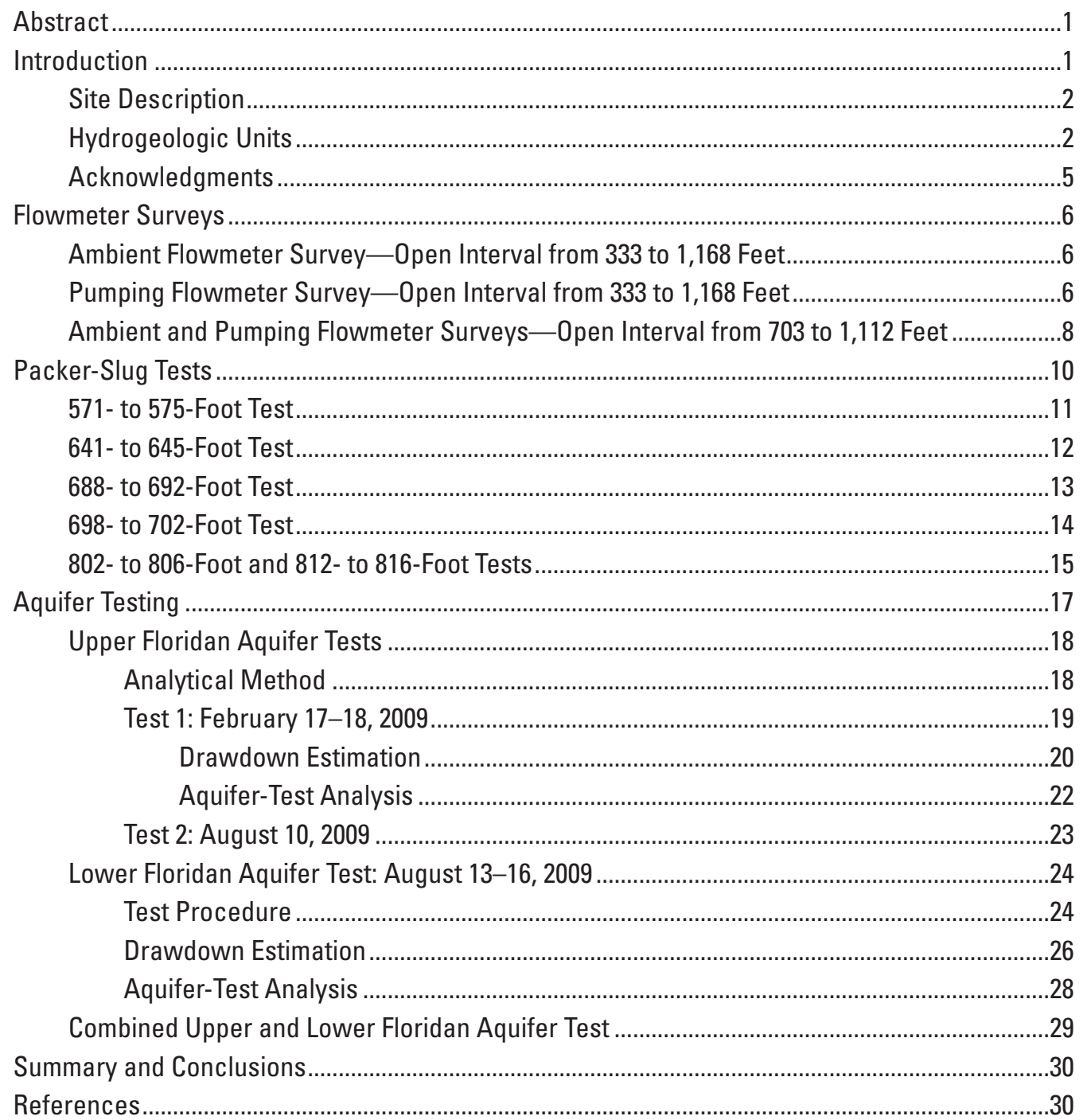




\section{Figures}

1. Maps showing location of study area, selected wells, and tidal station at Hunter Army Airfield and vicinity, Georgia ....

2. Borehole geophysical logs from well HAAF 11 (360392), Hunter Army Airfield, Chatham County, Georgia

3. Pumping and ambient flowmeter surveys completed on June 17, 2009, in well HAAF 11 (360392), Hunter Army Airfield, Chatham County, Georgia. Pumping survey through the 333-1,168 foot interval and ambient survey through the 333-1,168 foot interval

4. Pumping and ambient flowmeter surveys following completion of well HAAF 11 (360392), Hunter Army Airfield, Chatham County, Georgia. Pumping survey through the 333-1,112 foot interval collected on August 15, 2009, while pumping 747 gallons per minute, and ambient survey through the 333-1,112 foot interval collected on September 29, 2009

5-10. Graphs showing test data and analysis for packer-slug test in well HAAF 11 (360392), Hunter Army Airfield, Chatham County, Georgia-

5. Depth interval 571-575 feet, conducted on June 26, 2009

6. Depth interval 641-645 feet, conducted on June 26, 2009

7. Depth interval 688-692 feet, conducted on June 25, 2009

8. Depth interval 698-702 feet, conducted on June 25, 2009

9. Depth interval 802-806 feet, conducted on June 26, 2009

10. Depth interval 812-816 feet, conducted on June 25,2009

11. Location and construction characteristics of wells used for aquifer tests at Hunter Army Airfield, Chatham County, Georgia. Map showing aquifer test layout and schematic section showing the open intervals of the wells in relation to major hydrogeologic units.

12-16. Graphs showing-

12. Water-level data for well HAAF 9 (360391) during 24-hour aquifer test conducted February 17-18, 2009, Hunter Army Airfield, Chatham County, Georgia .

13. Comparison of water levels at well HAAF 8 (360292) to background water levels at Morrison Plantation observation well (360020) and to stage and barometric pressure at tidal gage 021989773 (U.S. Army Corps of Engineers Dock, Savannah, Georgia), Hunter Army Airfield, Chatham County, Georgia, February 12-26, 2009..

14. Effects of different time series components on development of a synthetic water level used to filter out extraneous trends for well HAAF 8 (360292), Hunter Army Airfield, Chatham County, Georgia...

15. Logarithmic plot of drawdown and time for observation well HAAF 8 (360292) located 2,020 feet from pumping well HAAF 9 for Upper Floridan aquifer test conducted February 17-18, 2009, Hunter Army Airfield, Chatham County, Georgia.

16. Logarithmic plot of drawdown and time for observation well HAAF 8 (360292) located 2,020 feet from pumping well HAAF 9 for Upper Floridan aquifer test conducted August 12, 2009, Hunter Army Airfield, Chatham County, Georgia ........23 
17-20. Graphs showing -

17. Drawdown response in Upper Floridan wells HAAF 8 (360292) and HAAF 5 (360288) during a 72-hour aquifer test of Lower Floridan well HAAF 11 (360392) conducted August 13-16, 2009, Hunter Army Airfield, Chatham County, Georgia.

18. Estimated drawdown in Upper Floridan aquifer wells HAAF 8 (360292) and HAAF 5 (360288) during a 72-hour aquifer test of Lower Floridan well HAAF 11 (360392) conducted August 13-16, 2009, Hunter Army Airfield, Chatham County, Georgia

19. Aquifer-test plots for 72-hour aquifer test of Lower Floridan aquifer conducted August 13-16, 2009, Hunter Army Airfield, Chatham County, Georgia. Log-log plot of drawdown and time and semi-logarithmic plot of residual drawdown and $t / t^{\prime}$

20. Aquifer-test plots for 6 -hour aquifer test of combined Upper and Lower Floridan aquifers in well HAAF 11 conducted June 19, 2009, Hunter Army Airfield, Chatham County, Georgia. Log-log plot of drawdown and time and semi-logarithmic plot of residual drawdown and $t / t^{\prime}$.

\section{Tables}

1. Location and completion intervals of wells used in the aquifer test analyses, Hunter Army Airfield, Chatham County, Georgia.

2. Horizontal hydraulic conductivity determined from packer-slug tests at well HAAF 11 (360392), Hunter Army Airfield, Chatham County, Georgia

3. Summary of transmissivity and storage cofficients determined from aquifer tests conducted in the Upper and Lower Floridan aquifers, Hunter Army Airfield, Chatham County, Georgia, 2009. 


\section{Conversion Factors}

\begin{tabular}{lcl}
\hline & Multiply & \multicolumn{1}{c}{ To obtain } \\
\hline inch & Length & \\
inch & 2.54 & centimeter $(\mathrm{cm})$ \\
foot (ft) & 25.4 & millimeter $(\mathrm{mm})$ \\
mile (mi) & 0.3048 & meter $(\mathrm{m})$ \\
& 1.609 & kilometer $(\mathrm{km})$ \\
\hline gallon (gal) & Volume & \\
gallon (gal) & 3.785 & liter $(\mathrm{L})$ \\
gallon (gal) & 0.003785 & cubic meter $\left(\mathrm{m}^{3}\right)$ \\
million gallons $(\mathrm{Mgal})$ & 3.785 & cubic decimeter $\left(\mathrm{dm}{ }^{3}\right)$ \\
\hline & 3,785 & cubic meter $\left(\mathrm{m}^{3}\right)$ \\
\hline foot per minute (ft/min) & Flow rate & \\
gallon per minute $(\mathrm{gal} / \mathrm{min})$ & 0.3048 & meter per minute $(\mathrm{m} / \mathrm{min})$ \\
inch per year (in/yr) & 0.06309 & liter per second $(\mathrm{L} / \mathrm{s})$ \\
\hline & 25.4 & millimeter per year $(\mathrm{mm} / \mathrm{yr})$ \\
\hline foot per day (ft/d) & Transmissivity* & \\
\hline foot squared per day (ft $/ \mathrm{d})$ & 0.09290 & meter squared per day $\left(\mathrm{m}^{2} / \mathrm{d}\right)$ \\
\hline
\end{tabular}

Vertical coordinate information is referenced to the North American Vertical datum of 1988 (NAVD 88). Historical data collected and stored as National Geodetic Vertical Datum of 1929 have been converted to NAVD 88 for this publication.

Horizontal coordinate information is referenced to the North American Datum of 1983 (NAD 83). Historical data collected and stored as North American Datum 1927 have been converted to NAD 83 for this publication.

*Transmissivity: The standard unit for transmissivity is cubic foot per day per square foot times foot of aquifer thickness [(ft $\left.\left.\mathrm{ft}^{3} \mathrm{~d}\right) / \mathrm{ft}^{2}\right] \mathrm{ft}$. In this report, the mathematically reduced form, foot squared per day $\left(\mathrm{ft}^{2} / \mathrm{d}\right)$, is used for convenience. 


\title{
Summary of Hydrologic Testing of the Floridan Aquifer System at Hunter Army Airfield, Chatham County, Georgia
}

\author{
By Lester J. Williams
}

\section{Abstract}

A 1,168-foot deep test well was completed at Hunter Army Airfield in the summer of 2009 to investigate the potential of using the Lower Floridan aquifer as a source of water supply to satisfy increased needs as a result of base expansion and increased troop levels. The U.S. Geological Survey conducted hydrologic testing at the test site including flowmeter surveys, packer-slug tests, and aquifer tests of the Upper and Lower Floridan aquifers.

Flowmeter surveys were completed at different stages of well construction to determine the depth and yield of waterbearing zones and to identify confining beds that separate the main producing aquifers. During a survey when the borehole was open to both the upper and lower aquifers, five waterbearing zones in the Upper Floridan aquifer supplied 83.5 percent of the total pumpage, and five water-bearing zones in the Lower Floridan aquifer supplied the remaining 16.5 percent. An upward gradient was indicated from the ambient flowmeter survey: 7.6 gallons per minute of groundwater was detected entering the borehole between 750 and 1,069 feet below land surface, then moved upward, and exited the borehole into lower-head zones between 333 and 527 feet below land surface. During a survey of the completed Lower Floridan well, six distinct water-producing zones were identified; one 17-foot-thick zone at 768-785 feet below land surface yielded 47.9 percent of the total pumpage while the remaining five zones yielded between 2 and 15 percent each.

The thickness and hydrologic properties of the confining unit separating the Upper and Lower Floridan aquifers were determined from packer tests and flowmeter surveys. This confining unit, which is composed of rocks of Middle Eocene age, is approximately 160 feet thick with horizontal hydraulic conductivities determined from four slug tests to range from 0.2 to 3 feet per day. Results of two separate slug tests within the middle confining unit were both 2 feet per day.
Aquifer testing indicated the Upper Floridan aquifer had a transmissivity of 40,000 feet squared per day, and the Lower Floridan aquifer had a transmissivity of 10,000 feet squared per day. An aquifer test conducted on the combined aquifer system, when the test well was open from 333 to 1,112 feet, gave a transmissivity of 50,000 feet squared per day. Additionally, during the 72-hour test of the Lower Floridan aquifer, a drawdown response was observed in the Upper Floridan aquifer wells.

\section{Introduction}

A 1,168-foot-deep test well was drilled at Hunter Army Airfield to investigate the potential of using the Lower Floridan aquifer as a source of water supply to satisfy increase needs due to base expansion. Hydrologic testing conducted in the test hole and the completed test well included flowmeter surveys, packer-slug tests, and aquifer tests of the Upper and Lower Floridan aquifers.

Well drilling was completed by Sam Martin Well Drilling of Dublin, Georgia, construction oversight and engineering was completed by AECOM of Raleigh, North Carolina, and geophysical logging and well testing was overseen by the U.S. Geological Survey (USGS). The test well was completed to a total depth of 1,168 feet (ft) on July 30, 2009. Hydrologic testing was completed to obtain data needed to develop a groundwater flow model that could be used to estimate the amount of leakage from the Upper Floridan aquifer that would result from the proposed withdrawal from the Lower Floridan well as required by Georgia Environmental Protection Division requirements for managing saltwater encroachment in the coastal areas of Georgia (Georgia Environmental Protection Division, 2003). 
Site-specific hydrologic testing was conducted in the summer of 2009 to determine the hydraulic characteristics of the Upper Floridan aquifer, middle-confining unit, and Lower Floridan aquifer at the test site. This report summarizes:

- Flowmeter surveys conducted in the Lower Floridan aquifer test well,

- Packer-slug tests conducted in the middle confining unit and intra-aquifer confining units of the Lower Floridan aquifer,

- A 24-hour aquifer test and a shorter-term (6-hour) aquifer test of the Upper Floridan aquifer,

- A 72-hour aquifer test of the Lower Floridan aquifer, and

- A 6-hour aquifer test on the combined Upper and Lower Floridan aquifers.

Location and construction details for the wells used as part of the hydraulic testing at HAAF are included in table 1.

\section{Site Description}

The U.S. Department of the Army (U.S. Army) Garrison Fort Stewart and Hunter Army Airfield (HAAF), Georgia, is located in central Chatham County, Georgia (fig. 1). The study area is characterized by flat topography and sandy topsoil typical of the Georgia coastal area. The study area has a mild climate with warm, humid summers and mild winters. During 1971-2000, precipitation at the Savannah Airport averaged about 49 inches per year. Maximum monthly rainfall (exceeding 4 inches per month) generally occurs during JuneSeptember, with monthly rainfall totals typically less than 4 inches during the rest of the year.

\section{Hydrogeologic Units}

The Savannah area is underlain by a thick sequence of unconsolidated to semiconsolidated sands, clays, and limestone/dolomite rock units ranging in age from Cretaceous to recent. These formations have varying degrees of porosity and permeability and form multiple aquifer systems, including, from shallowest to deepest, the surficial, Brunswick, and Floridan aquifer systems. The Floridan aquifer system is subdivided into the Upper and Lower Floridan aquifers (Miller, 1986; Falls and others, 2005). The Floridan aquifer system is confined by overlying clay layers and is separated into several permeable water-bearing zones by layers of denser limestone/ dolomite that act as semiconfining units allowing vertical leakage of groundwater to enter the Upper or Lower Floridan aquifers, depending on the vertical hydraulic conductivity and head gradient (Miller, 1986; Clarke and others, 1990). In the Savannah area, current-meter (flowmeter) tests conducted in deep wells indicate there are at least five permeable zones within the Floridan aquifer system (McCollum and Counts, 1964). A generalized correlation of hydrogeologic and geologic units to borehole geophysical logs and flowmeter data at HAAF is shown in figure 2.

Geophysical logs and flowmeter surveys indicate the Upper Floridan aquifer is $309 \mathrm{ft}$ thick at the test well location. The Upper Floridan aquifer is overlain by a 187 -ft-thick confining layer consisting mostly of clay of the Hawthorn Formation and underlain by an approximately 160 -ft-thick semiconfining layer consisting mostly of fine-grained limestone and dolomitic limestone of the Avon Park Formation. This interpretation is supported by the evaluation of drill cuttings, flowmeter logs, and geophysical logs completed for the test well.

Table 1. Location and completion intervals of wells used in the aquifer test analyses, Hunter Army Airfield, Chatham County, Georgia.

[See fig. 1 for site locations; UF, Upper Floridan; LF, Lower Floridan; —, no HAAF number, not located on base]

\begin{tabular}{|c|c|c|c|c|c|c|c|c|c|}
\hline $\begin{array}{l}\text { HAAF } \\
\text { number }\end{array}$ & $\begin{array}{c}\text { USGS } \\
\text { identification }\end{array}$ & Site number & $\begin{array}{l}\text { Land } \\
\text { elevation** }\end{array}$ & Latitude & Longitude & \multicolumn{3}{|c|}{ Values, in feet below land surface } & Aquifer \\
\hline 8 & 36Q292 & 320003081102301 & 22 & 32.00086 & -81.17257 & 63.12 & 255 & 375 & UF \\
\hline 9 & 36Q391 & 320018081100601 & 16.3 & 32.00512 & -81.16831 & 59.02 & 295 & 425 & UF \\
\hline- & $36 \mathrm{Q} 020 * * *$ & 320021081124801 & 13 & 32.00604 & -81.21317 & 47.78 & 330 & 336 & UF \\
\hline
\end{tabular}

*Measured 8/10/2009

${ }^{* *}$ Datum is NGVD 29

${ }^{* * *}$ Located at Morrison Plantation; used as a background monitoring well 

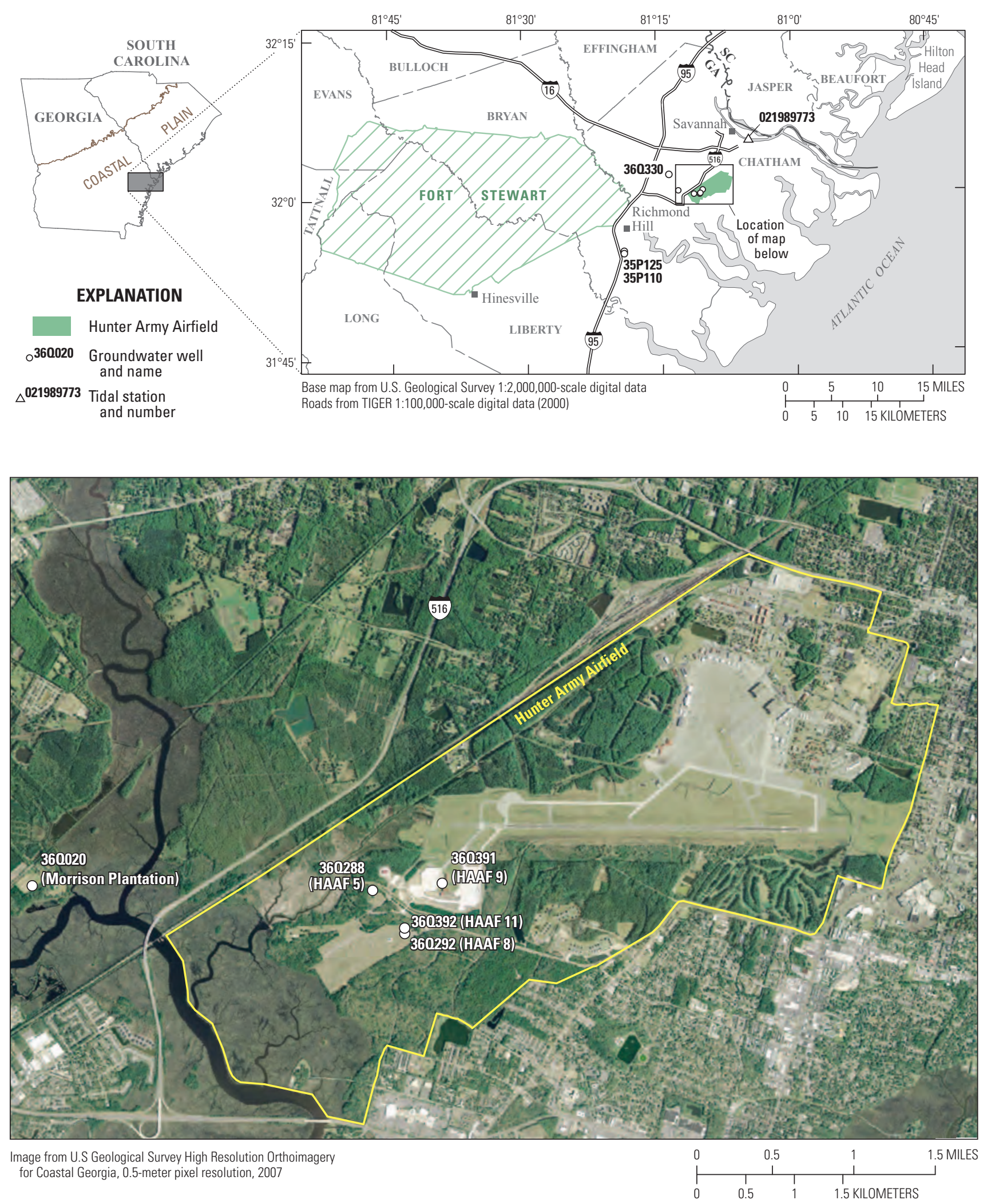

Figure 1. Location of study area, selected wells, and tidal station at Hunter Army Airfield and vicinity, Georgia. 


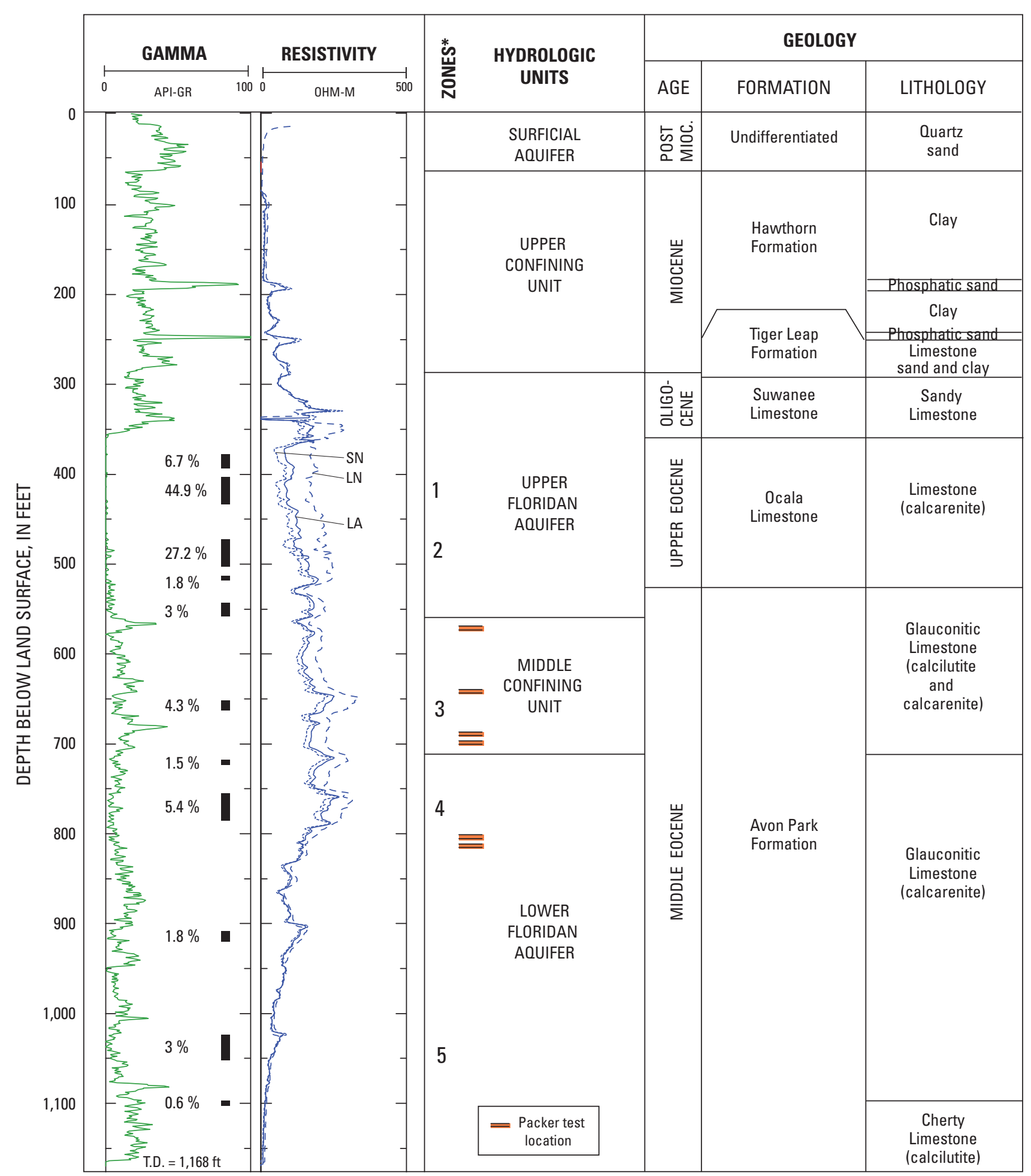

Figure 2. Borehole geophysical logs from well HAAF 11 (360392), Hunter Army Airfield, Chatham County, Georgia. Black bars denote water-bearing zone and percentage of flow determined from pumping flowmeter test while pumping 847 gallons per minute. [LN, long normal resistivity; SN, short normal resistivity; LA, lateral resistivity; *zones 1 through 5 correlate to water-bearing zones previously defined in the area by McCollum and Counts, 1964] 


\section{Acknowledgments}

Many people participated in the successful completion of this study. Stanley Thomas with the U.S. Department of the Army is gratefully acknowledged for his help with the overall coordination between the U.S. Army, USGS, and civilian contractors. He provided assistance whenever needed and was a large part of the success of this project. Numerous people from the base's water department helped during the project, including Nathanial Williams, Donald Highsmith, and Terry Howard who helped with coordination and modification of pumping schedules needed to complete the tests. From AECOM, Robert McManus, Peter Thibodeau and John Funk are acknowledged for their work with on-site coordination, engineering, safety, and provided assistance when needed during the completion of the testing program. Dwight Robertson and Beth Mitchell of Oak Ridge National Laboratory are acknowledged for their work with the contracting performed for the project. Many thanks is given to Owen (Gary) Holloway of the USGS who helped to design and construct the packer assembly used in this study and was present throughout the fieldwork portion of the study. 


\section{Flowmeter Surveys}

Flowmeter surveys were performed at different stages of well construction to identify the depth intervals and yields of water-bearing zones and confining beds that separate the main producing aquifers. Ambient and pumping surveys also were performed to obtain information about hydraulically active zones in the open portion of the borehole.

\section{Ambient Flowmeter Survey-Open Interval from 333 to 1,168 Feet}

The first flowmeter survey, conducted on June 17, 2009, was used to traverse the borehole under ambient (nonpumping) conditions. The goal of this survey was to determine the flow conditions (up or down) in the borehole under ambient conditions. During this stage of construction, the well was open from 333 to $1,168 \mathrm{ft}$, an interval that includes both the Upper and Lower Floridan aquifers.

To conduct this survey, a rubber skirt was attached to the outside of an electromagnetic (EM) flowmeter to divert flow through the center of the tool and, thus, increase sensitivity of the tool. The skirt prevents flow from bypassing the tool except in areas of borehole enlargement where the skirt is not fully sealed against the borehole wall. Using this "skirt-on" configuration, the EM flowmeter is capable of measuring flow rates of between 0.01 and 10 gallons per minute ( $\mathrm{gal} / \mathrm{min})$.

The results of the flowmeter survey indicate that, under ambient conditions, groundwater enters the borehole from higher-head zones of the Lower Floridan aquifer, moves upward, and then exits into lower-head zones of the Upper Floridan aquifer. Water inflows, or gains, were observed between the $1,069 \mathrm{ft}$ and $750 \mathrm{ft}$ interval at specific zones, reaching a maximum upward flow rate of $7.6 \mathrm{gal} / \mathrm{min}$ at a depth of $750 \mathrm{ft}$. The increase in flow through this section of the borehole is illustrated by a stair-step pattern that indicates flow contribution from several discrete zones rather than contribution from the entire thickness of the Lower Floridan aquifer (fig. $3 B$ ). This interpretation is consistent with the observed response during the pumping flowmeter survey (described below). Above $750 \mathrm{ft}$, within the interval of the confining unit, several of the flowmeter measurements plot to the left of the interpreted profile. These points suggest that a significant amount of water was likely bypassing the tool at these flow-measurement stations. Flow bypass was interpreted to occur along sections of enlarged borehole where the skirt was not fully fit across the borehole. Between the $333 \mathrm{ft}$ and $527 \mathrm{ft}$ depth interval, flow decreased back toward zero, indicating that groundwater exits the borehole along permeable sections of limestone in the Upper Floridan aquifer.

\section{Pumping Flowmeter Survey-Open Interval from 333 to 1,168 Feet}

A pumping flowmeter survey was performed on June 19, 2009 , to determine relative contribution of the water-bearing zones under a stressed condition and to assist in identifying low or "no flow" zones that may correlate to regional or local confining units within the aquifer system. To conduct this survey, the EM flowmeter was run in a "skirt-off" configuration, allowing some of the flow to bypass the tool to allow for greater flow-rate ranges.

On June 18, 2009, an electric submersible pump was installed in the test well to a depth of $120 \mathrm{ft}$. A 4-inch polyvinyl chloride (PVC) stilling well was also installed at this time to provide access for the EM flowmeter and a pressure transducer to be placed below the depth of the pump in the test well. On the next day (June 19, 2009), the pump was started at 07:28 a.m. Eastern Standard Time (EST) at a constant flow rate of $847 \mathrm{gal} / \mathrm{min}$. This rate was held steady throughout the next 6 hours, the time that it took to complete the flowmeter surveys. A pressure transducer in the stilling well inside the test well was used to monitor water-level stabilization after pump startup. Following water-level stabilization, two separate logs were collected. The first log was collected in a "trolling mode," moving the tool down hole at a constant rate of 10 feet per minute ( $\mathrm{ft} / \mathrm{min}$ ). This log provided a continuous flow profile along the length of the open borehole. The trolling log was started inside the casing, to obtain a baseline EM-tool response in counts per second (CPS) at a known casing diameter and known pumping rate. Once in the open portion of the borehole, the flowmeter was used to traverse and quantify the relative contribution from each water-bearing zone. The percentage of total pumpage attributed to any one zone was calculated by using the ratio of the gain in CPS (corrected for casing diameter) across the zone tested to the counts per minute in the casing. Corrections for irregular borehole diameter were made from the caliper log.

The exaggerated flow (above the actual flow rate of $847 \mathrm{gal} / \mathrm{min}$ ) identified below the casing was determined to be an artifact of turbulent flow and borehole enlargements in this portion of the borehole and was not used for quantifying borehole flow (fig. $3 A$ ).

An additional pumping flowmeter survey was performed in a stationary-point mode whereby the tool was positioned at specific depths and allowed to stabilize before the flow measurement was made. The resulting stationary point log consisted of single measurements along the borehole that were used to calibrate and adjust the readings from the trolling log produced from the first flowmeter survey (see open circles in figure 3 ). 
A

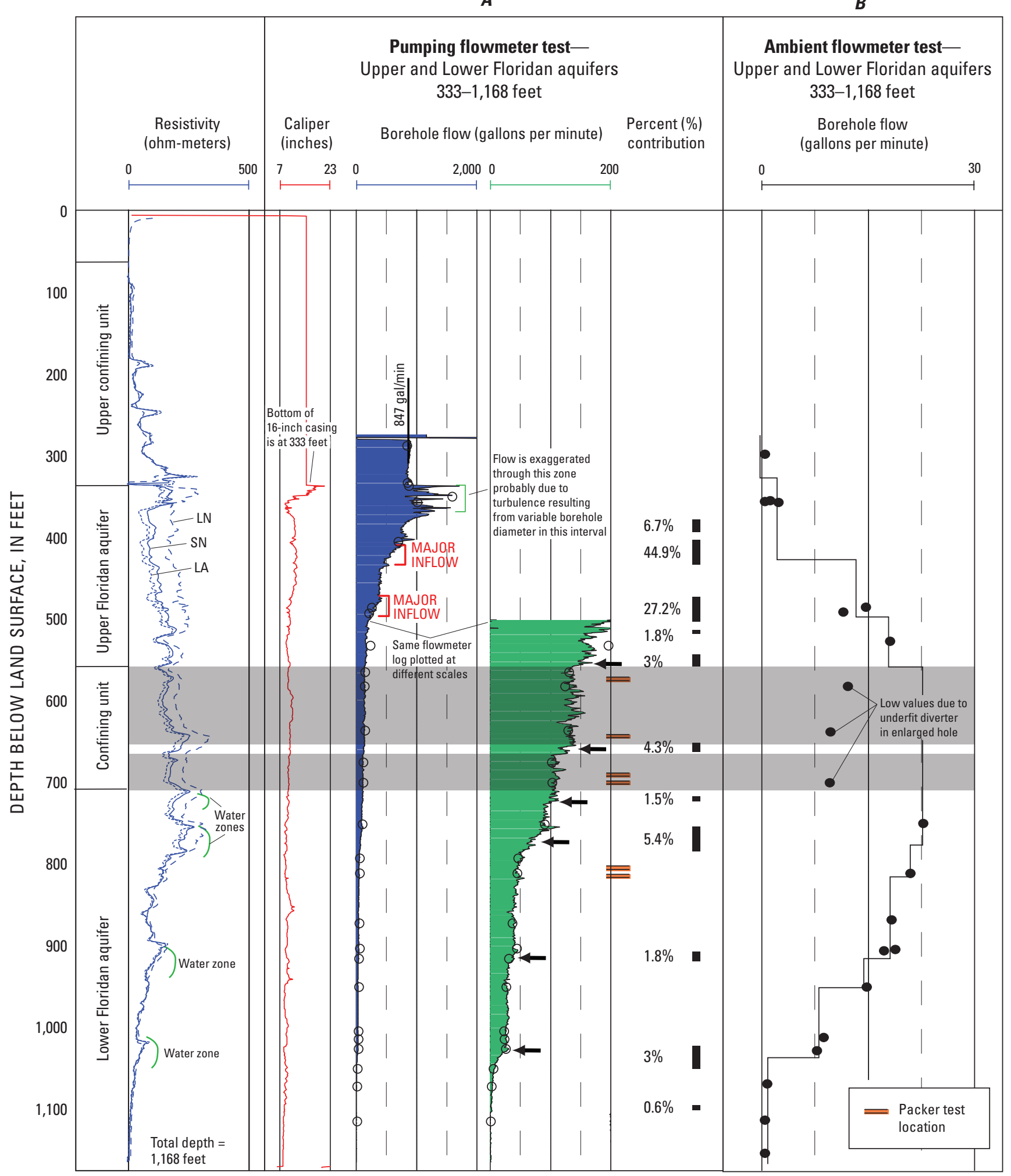

Figure 3. Pumping and ambient flowmeter surveys completed on June 17, 2009, in well HAAF 11 (360392), Hunter Army Airfield, Chatham County, Georgia. (A) Pumping survey through the 333-1,168 foot interval, (B) Ambient survey through the 333-1,168 foot interval. Open circles are stationary point measurements taken during pumping survey. Solid circles are stationary point measurements taken during ambient (nonpumping) survey. Arrows indicate water-producing zones. [LN, long normal resistivity; SN, short normal resistivity; LA, lateral resistivity] 
The trolling flowmeter log is represented on two scales to emphasize zones of groundwater inflow into the borehole during pumping (fig. 3). Two major and several minor inflow zones were identified within the Upper Floridan aquifer, as shown on the $0-2,000 \mathrm{gal} / \mathrm{min}$ scale on the left side of figure 3 ; five separate zones can be distinguished, which together supply 83.5 percent of the total pumpage or $707 \mathrm{gal} / \mathrm{min}$. Deeper water-bearing zones in the confining unit and Lower Floridan aquifer are denoted with left-facing arrows along the $\log$ on the $0-200 \mathrm{gal} / \mathrm{min}$ scale (fig. 3). The depth intervals for each of these zones are denoted by the black bars in figure 3 . Collectively, the deeper zones in the confining unit and Lower Floridan aquifer supply the remaining 16.5 percent of the total pumpage or $140 \mathrm{gal} / \mathrm{min}$.

The depth and thickness of confining bed(s) separating the Upper and Lower Floridan aquifers were determined by identifying vertically continuous sections that exhibited little to no flow contribution on the flowmeter logs (fig. 3). The interpreted confining unit is indicated by gray shading in figure 3 . Two primary confining beds were identified in the flowmeter survey logs: a 94-ft-thick section between 560 and $654 \mathrm{ft}$, and a 55 -ft-thick section between 665 and $720 \mathrm{ft}$. These two zones combine to form a semiconfining bed that is correlated to other nearby wells. One water-producing zone was identified inside the confining bed, which produced 4.3 percent of the total pumpage during the flowmeter survey. Based on interpretation of the flowmeter logs, the confining layer was estimated to be approximately $160 \mathrm{ft}$ thick at the test site.

\section{Ambient and Pumping Flowmeter Surveys- Open Interval from 703 to 1,112 Feet}

Information gathered from the flowmeter surveys, along with examination of drill cuttings and correlation of the confining bed to nearby wells, was used to make decisions on the final well construction. The initial test hole was completed with 8-inch steel casing, set to a depth of $703 \mathrm{ft}$, with an open interval from 703 to $1,112 \mathrm{ft}$. Following well completion, additional flowmeter surveys were run in the well to further evaluate the depth and location of the water-bearing zones. These surveys were run to verify the hydraulic characteristics of the previously identified water-bearing zones in the completed well, because these zones may change after the completion of the well.
A pumping flowmeter survey was conducted on August 15, 2009, during the last day of the 72-hour pumping test (described below). The pumping rate during this survey was $747 \mathrm{gal} / \mathrm{min}$. The ambient flowmeter survey was performed on September 29, 2009.

During the pumping flowmeter survey, both trolling and stationary point logs were collected (fig. 4). The trolling log was started inside the casing to obtain initial readings representative of the maximum pumping rate. Once in the open portion of the borehole, the flowmeter was used to traverse and quantify the relative contribution from each water-bearing zone along the open interval. Exaggerated flow identified below the casing is likely an artifact of turbulent flow and borehole enlargements in that portion of the borehole and was not used for quantifying borehole flow. The stationary point log consisted of collecting single measurements along the borehole and was used to calibrate and adjust the readings from the trolling log (see open circles in figure 4).

The trolling flowmeter log is represented on two scales to emphasize zones of groundwater inflow into the borehole during pumping (fig. 4). Several major and minor inflow zones were identified within the Lower Floridan aquifer, as shown on the $0-1,000 \mathrm{gal} / \mathrm{min}$ scale on the left side of figure 4 ; three zones are distinguished in the upper part of the aquifer, which together produce 73.4 percent of the total pumpage or $550 \mathrm{gal} / \mathrm{min}$. One of these zones, a 17 -ft-thick waterbearing interval from 768 to $785 \mathrm{ft}$, produced 47.9 percent or $359 \mathrm{gal} / \mathrm{min}$ of the $747 \mathrm{gal} / \mathrm{min}$ being pumped. Two deeper zones that were identified supply the remaining 19.7 percent of the total pumpage or $147.8 \mathrm{gal} / \mathrm{min}$. The depth and relative yield of the water-bearing zones in the completed well are consistent with flowmeter logs collected earlier in the study.

The location and approximate contribution from waterproducing zones detected in the flowmeter survey completed from 703 to $1,112 \mathrm{ft}$ compares fairly well to the survey that was completed in the interval from 333 to $1,168 \mathrm{ft}$. The only large difference is the water-producing zone at $818-837 \mathrm{ft}$, which produced about 11 percent of the total amount of water from the well, but did not produce any water during the earlier test. The reason for this change may be related to the fact that in the final well completion the well is pumped with a larger drawdown, thus changing the hydraulics of the waterproducing zones in the open interval. 


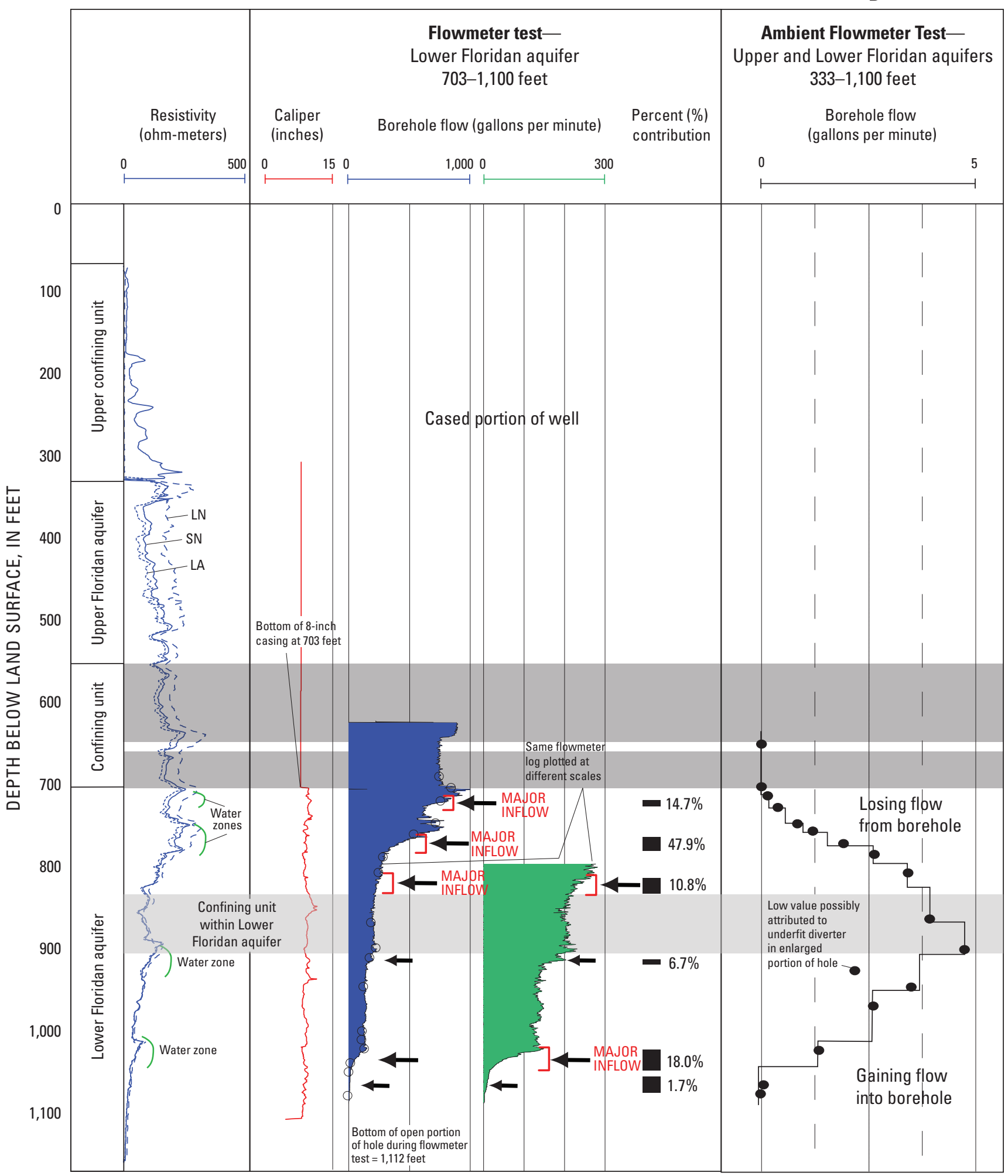

Figure 4. Pumping and ambient flowmeter surveys following completion of well HAAF 11 (360392), Hunter Army Airfield, Chatham County, Georgia. (A) Pumping survey through the 333-1,112 foot interval collected on August 15, 2009, while pumping 747 gallons per minute, (B) Ambient survey through the 333-1,112 foot interval collected on September 29, 2009. Open circles are stationary point measurments taken during pumping survey. Solid circles are stationary point measurements taken during ambient (nonpumping) survey. Arrows indicate water-producing zones. Black bars denote the major inflow zones and percent of the total pumpage each zones produces. [LN, long normal resistivity; LA, lateral resistivity] 


\section{Packer-Slug Tests}

Hydraulic conductivity estimates of the middle confining unit and lower permeability material of the Lower Floridan aquifer were obtained by conducting packer-slug tests at six depth intervals in well HAAF 11 (36Q392): $571-575 \mathrm{ft}, 641-645 \mathrm{ft}, 688-692 \mathrm{ft}, 698-702 \mathrm{ft}, 802-806 \mathrm{ft}$, and $812-816 \mathrm{ft}$ (fig. 2). The four uppermost intervals are located within the middle confining unit, and the two lower intervals are located within the Lower Floridan aquifer. Each interval was isolated using straddle packers, then a slug of water was injected into the interval, and the rate of head decline was recorded. Data were analyzed for horizontal hydraulic conductivity using the Bouwer and Rice (1976) method. Pressure transducers were used to monitor waterlevel response within the isolated interval as well as above and below the zone being tested. The general procedures for conducting these tests were as follows:

1. Lower packer assembly to the target depth.

2. Attach pressure transducers to dataloggers and start recording at 2-second intervals.

3. Inflate upper packer to full seating pressure.

4. Inflate lower packer to full seating pressure.

5. Allow water level in the test interval to stabilize (typically 10 minutes).

6. Inject water into the isolated interval through the drill stem to raise the water level within the test interval.

7. Monitor the falling water level until water levels return to pre-test conditions.

8. Review pressure data from upper and lower intervals to check for indications of leakage across the straddle packers; re-inflate or reposition packers if necessary.

9. Deflate packers and move to the next depth interval.
The caliper log was used to position the packers, selecting smooth sections of the borehole that would be more likely to have the greatest potential for good packer seating. Vugs, solution cavities, and irregular borehole enlargements were identified so that the rubber packers would not be inflated along these irregular surfaces.

Slug test data were analyzed with the Bouwer and Rice (1976) method to obtain estimates of hydraulic conductivity (table 2). The Bouwer and Rice (1976) method assumes the aquifer has an infinite areal extent, is homogeneous, and has a uniform thickness; the test well is fully or partially penetrating; effects of storage are negligible; flow to the well is quasi-steady state; and the slug is introduced into the well instantaneously. AQTESOLVTM version 4.5 was used to analyze the tests; the resulting plots are shown in figures 5 through 10 , and a summary of the test results is listed in table 2 . The following were specified in the analysis of each test:

- well-screen length: $4 \mathrm{ft}$ (distance measured between packers)

- well radius: $0.375 \mathrm{ft}$ (measured from caliper log)

- casing radius: $0.10 \mathrm{ft}$ (drill-rod radius)

Table 2. Horizontal hydraulic conductivity determined from packer-slug tests at well HAAF 11 (360392), Hunter Army Airfield, Chatham County, Georgia.

\begin{tabular}{|ccc|}
\hline $\begin{array}{c}\text { Hydrogeologic } \\
\text { unit }\end{array}$ & $\begin{array}{c}\text { Interval } \\
\text { (feet below } \\
\text { land surface) }\end{array}$ & $\begin{array}{c}\text { Horizontal } \\
\text { hydraulic } \\
\text { conductivity } \\
\text { (feet per day)* }\end{array}$ \\
\hline Middle confining unit & $571-575$ & 1.1 \\
& $641-645$ & 3.1 \\
$688-692$ & 0.16 \\
Lower Floridan & $698-702$ & 0.20 \\
aquifer & $802-806$ & 1.7 \\
\hline
\end{tabular}

*Estimated using Bouwer and Rice (1972) method 


\section{1- to 575-Foot Test}

The first slug test was completed at a depth interval of 571-575 ft, within the upper part of the Lower Floridan aquifer confining bed. To initiate the test, a 5.8-gallon (gal) slug of water was introduced into the isolated interval through the drill stem, which caused a water-level displacement of $12 \mathrm{ft}$ within the first 20 seconds followed by a slow decline of the water level back to within $0.01 \mathrm{ft}$ of the initial water level within approximately 4 minutes (fig. 5). Because of the non-instantaneous test initiation, the translation method of Pandit and Miner (1986) was applied prior to analyzing the data. (This same correction was applied to all tests described below.) A semi-logarithmic plot of the falling-head data produced a straight-line fit, with a calculated horizontal hydraulic conductivity of 1.1 feet per day (ft/d) for this test.

Water levels in the upper and lower intervals were steady throughout the test, indicating no observable leakage during slug injection or decline. Total water-level displacement across the interval after achieving full seating pressure was a positive $0.72 \mathrm{ft}$ (upper zone water level of $64.14 \mathrm{ft}$ minus lower zone water level of $63.42 \mathrm{ft}$ ), indicating an upward flow gradient across this depth interval.

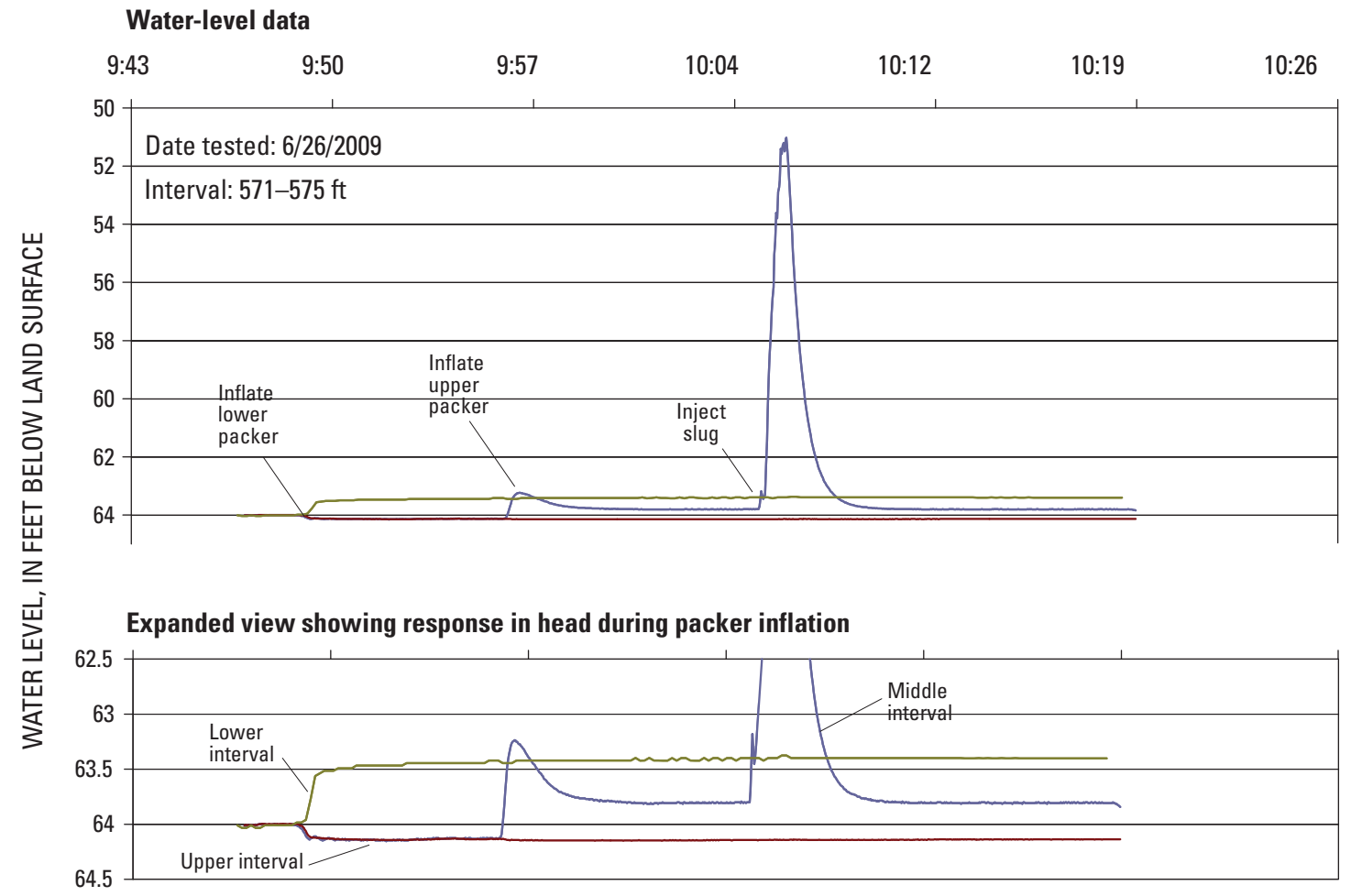

Analysis

Casing radius: $\quad 0.1 \mathrm{ft}$

Screen length: $4.0 \mathrm{ft}$

Well radius: $0.375 \mathrm{ft}$

Static water level:

64.01

Shut-in water levels:

\begin{tabular}{cc} 
Zone & WLBLS \\
\hline Upper & 64.14 \\
Middle & 63.80 \\
Lower & 63.42 \\
\hline
\end{tabular}

WLBLS = water level below land surface

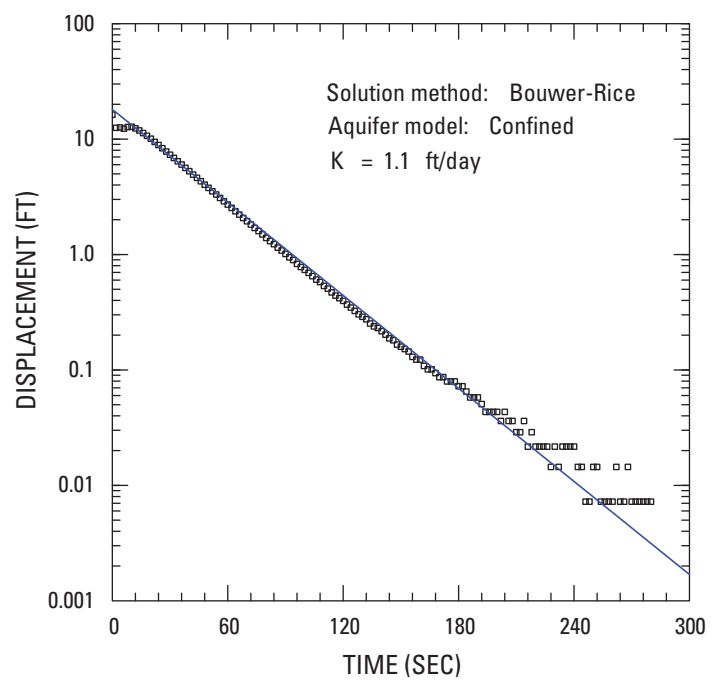

Figure 5. Test data and analysis for packer-slug test of depth interval 571-575 feet in well HAAF 11 (360392), Hunter Army Airfield, Chatham County, Georgia, conducted on June 26, 2009. 


\section{1- to 645-Foot Test}

The second slug test was completed at the 641 - to $645-\mathrm{ft}$ depth interval, located within the upper part of the middle confining unit. For this interval, a 5.8-gal slug of water caused a water-level displacement of $6 \mathrm{ft}$ within the first 35 seconds, and then a rapid decline of the water level back to within $0.01 \mathrm{ft}$ of the initial water level within 1.5 minutes. The best fit for the data on the semi-logarithmic plot was selected between 10 and 60 seconds, resulting in a calculated horizontal hydraulic conductivity of $3.1 \mathrm{ft} / \mathrm{d}$ for this test (fig. 6).

Water levels in the upper and lower intervals were steady throughout the test, indicating no observable leakage during slug injection or decay. Total water-level displacement across the interval after achieving full seating pressure was a positive $0.79 \mathrm{ft}$ (upper zone water level of $64.28 \mathrm{ft}$ minus lower zone water level of $63.49 \mathrm{ft}$ ), indicating a slight increase in the upward flow gradient compared to the previously described test interval.

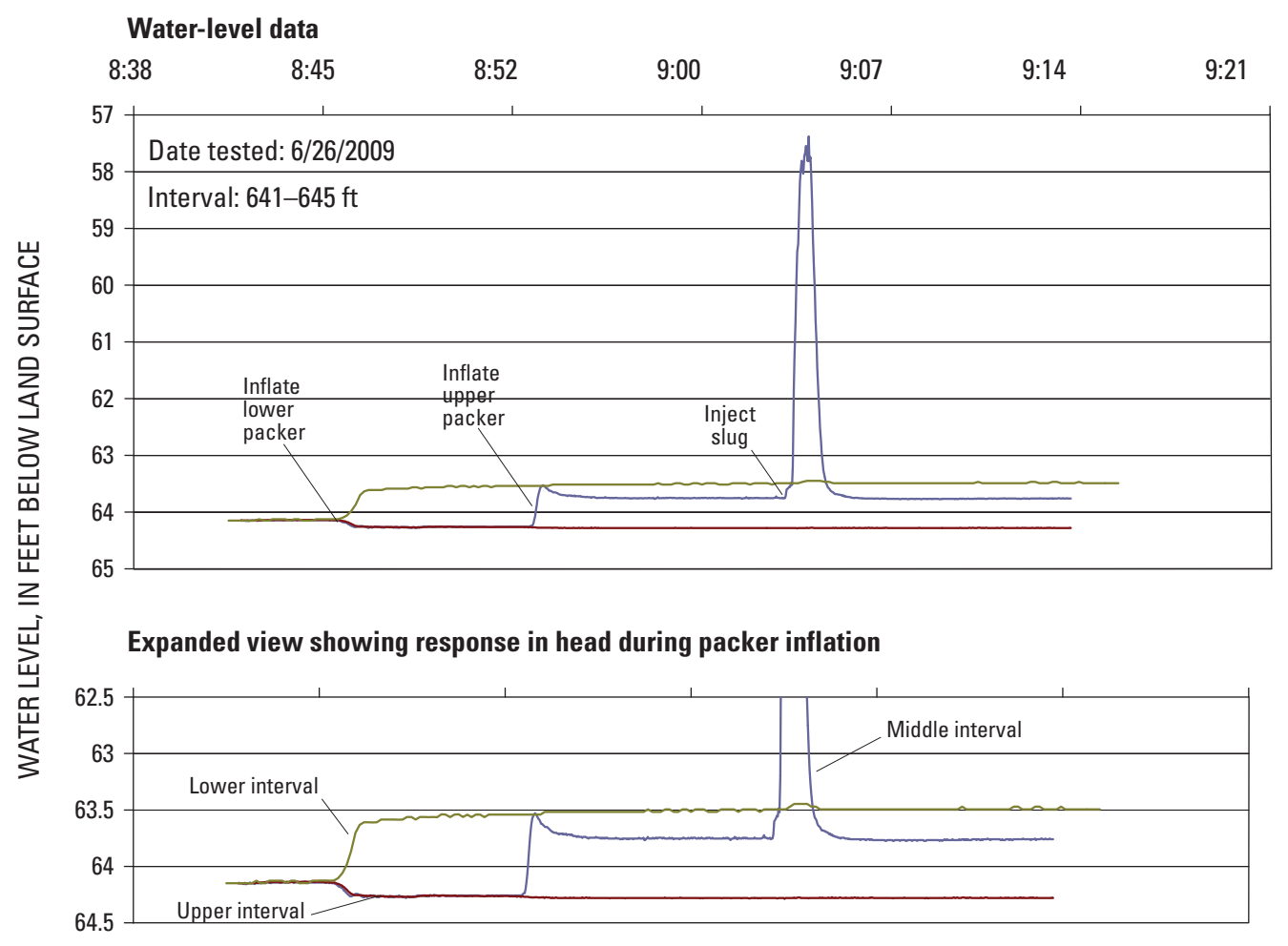

Analysis

Casing radius: $\quad 0.1 \mathrm{ft}$

Screen length: $\quad 4.0 \mathrm{ft}$

Well radius: $0.375 \mathrm{ft}$

\begin{tabular}{cc}
$\begin{array}{cc}\text { Static water Level: } \\
\text { Shut-in water levels: } \\
\text { Zone }\end{array}$ & 64.15 \\
\hline Upper & WLBLS \\
\hline Middle & 64.28 \\
Lower & 63.75 \\
\hline
\end{tabular}

WLBLS $=$ water level below land surface

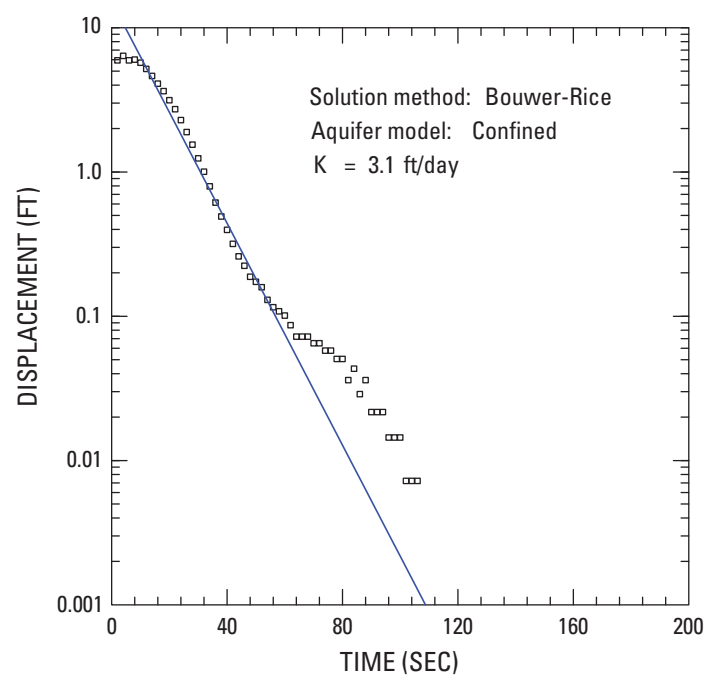

Figure 6. Test data and analysis for packer-slug test of depth interval 641-645 feet in well HAAF 11 (360392), Hunter Army Airfield, Georgia, conducted on June 26, 2009. 


\section{8- to 692-Foot Test}

The third slug test was completed at the 688 - to $692-\mathrm{ft}$ depth interval, located within the lower part of the middle confining unit. For this interval, the 5.8-gal slug of water introduced into the isolated interval through the drill stem caused a water-level displacement of $16 \mathrm{ft}$ within the first 40 seconds followed by a slow decay of the water level back to within $0.01 \mathrm{ft}$ of the initial water level within approximately $15 \mathrm{~min}$ utes. After translating the data to account for the test initiation, a straight line fit to the data between 0 and 400 seconds on the semi-logarithmic plot resulted in a calculated horizontal hydraulic conductivity of $0.16 \mathrm{ft} / \mathrm{d}$ for this test (fig. 7).

Water levels in the upper and lower intervals were steady throughout the test, indicating no observable leakage during slug injection or decay. Total water-level displacement across the interval after achieving full seating pressure was a positive $0.65 \mathrm{ft}$ (upper zone water level of $63.71 \mathrm{ft}$ minus lower zone water level of $63.06 \mathrm{ft}$ ), indicating a decreased flow gradient across this depth interval compared to the previous depth interval.

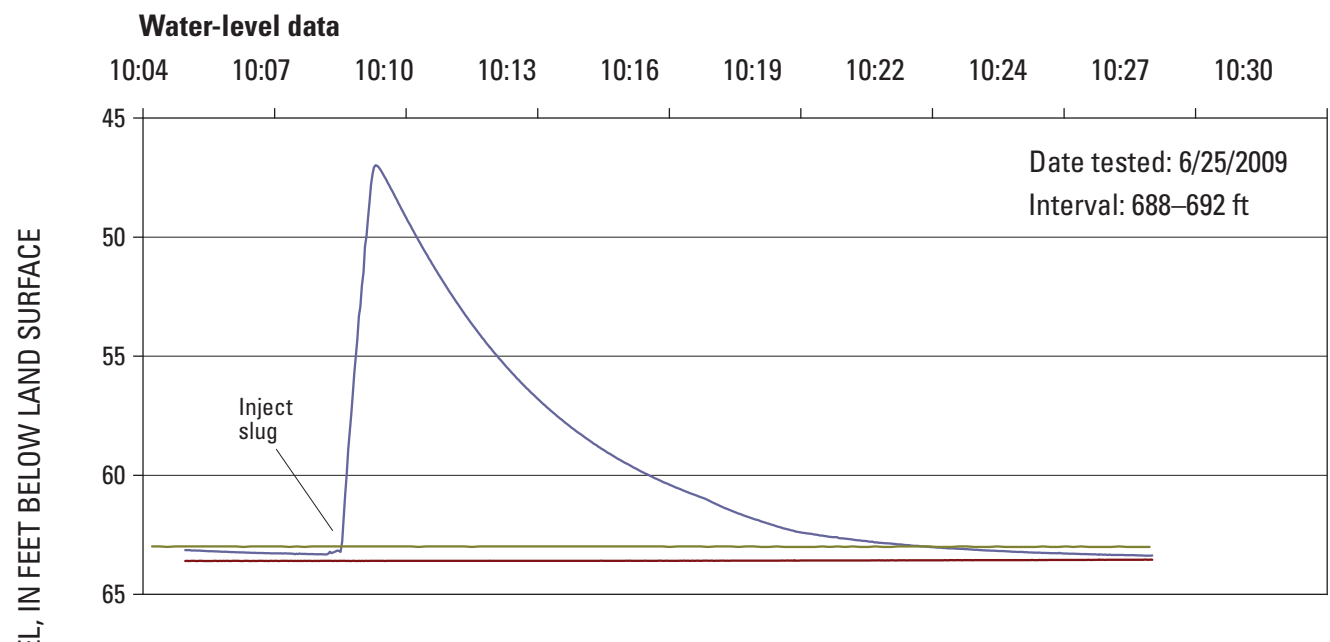

Expanded view showing response in head during packer inflation

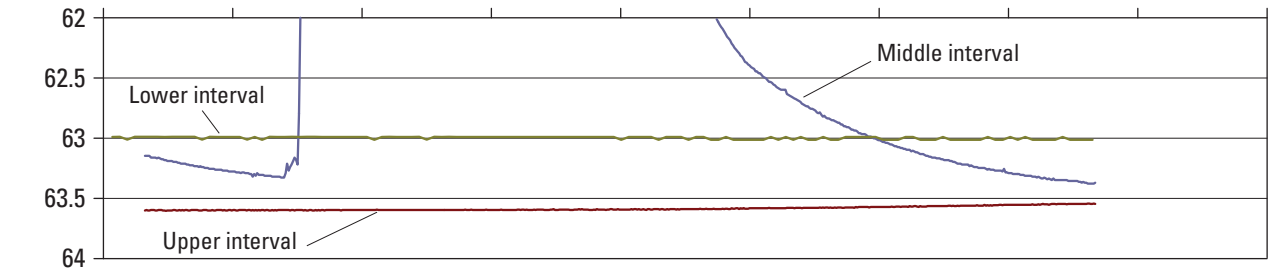

Analysis

Casing radius: $\quad 0.1 \mathrm{ft}$

Screen length: $\quad 4.0 \mathrm{ft}$

Well radius: $0.375 \mathrm{ft}$

Static water level:

63.53

Shut-in water levels:

Zone WLBLS

Upper $\quad 63.71$

Middle $\quad 63.6$

Lower

63.06

WLBLS = water level below land surface Note: shut-in water levels from slug test done at 09:07

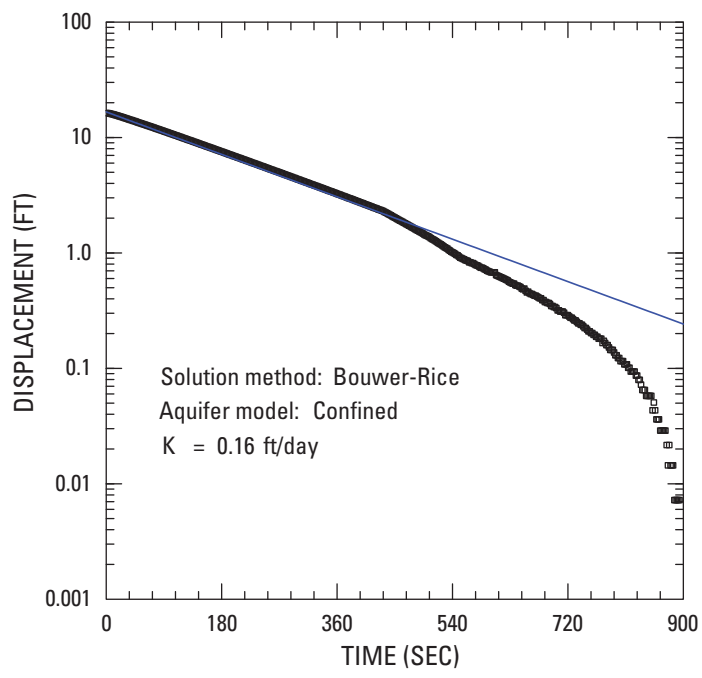

Figure 7. Test data and analysis for packer-slug test of depth interval 688-692 feet in well HAAF 11 (360392), Hunter Army Airfield, Georgia, conducted on June 25, 2009. 


\section{8- to 702-Foot Test}

The fourth slug test was completed at the 698 - to $702-\mathrm{ft}$ depth interval, located in the middle confining unit and near the bottom contact with the Lower Floridan aquifer. For this interval, the 5.8-gal slug of water introduced into the isolated interval through the drill stem displaced the water level $21 \mathrm{ft}$ within the first 45 seconds followed by a slow decay of the water level back to within $0.02 \mathrm{ft}$ of the initial water level within approximately 18 minutes. The best fit is a straight line between 0 and 940 seconds on the semi-logarithmic plot, giving a horizontal hydraulic conductivity of $0.2 \mathrm{ft} / \mathrm{d}$ for this test (fig. 8).

Water levels in the upper and lower intervals were steady throughout the test, indicating no observable leakage during slug injection or decay. Total water-level displacement across the interval after achieving full seating pressure was a positive $0.82 \mathrm{ft}$ (upper zone water level of $63.67 \mathrm{ft}$ minus lower zone water level of $62.85 \mathrm{ft}$ ), indicating an increased flow gradient at this depth compared to the previous interval.

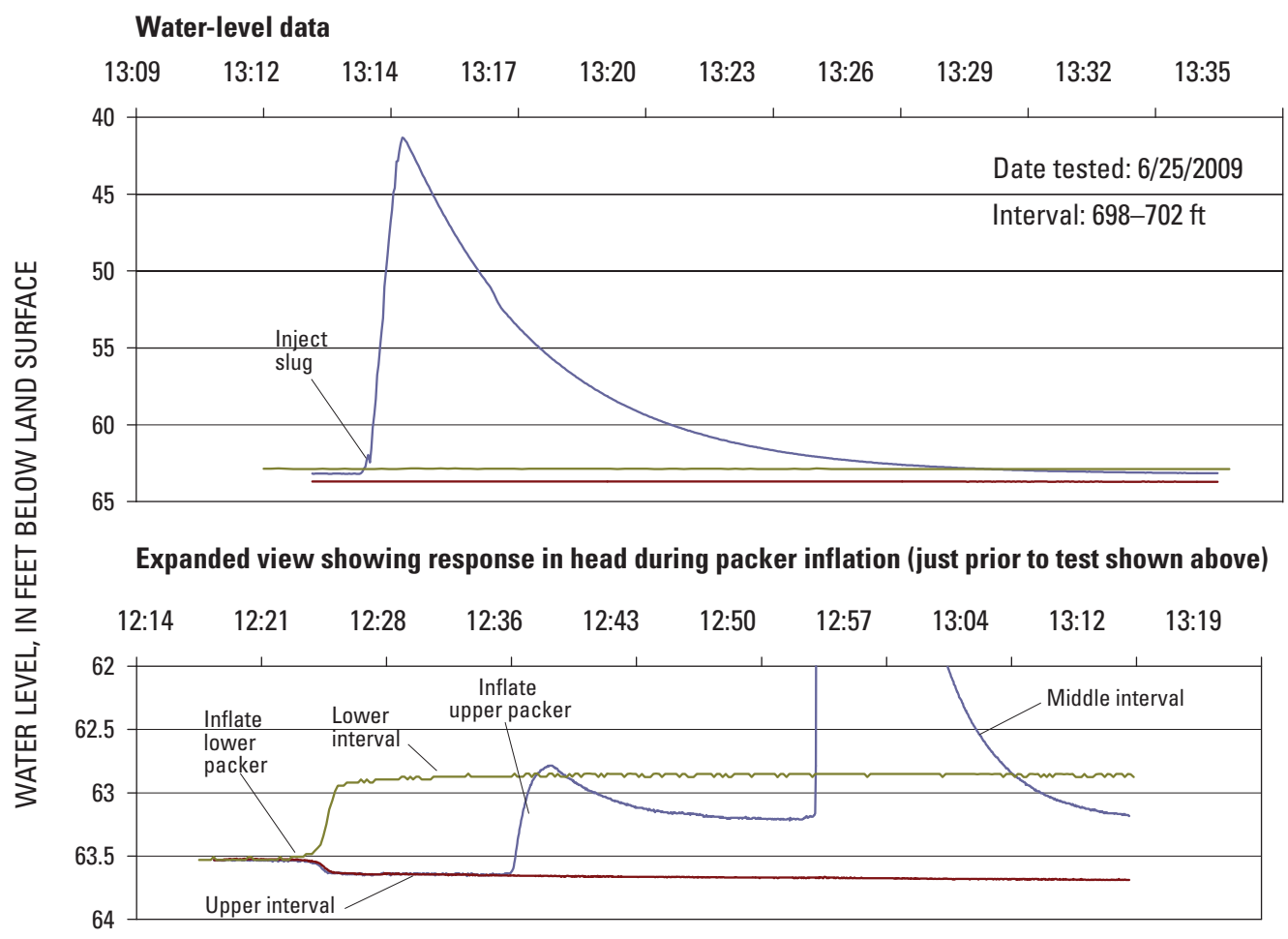

\begin{tabular}{|c|c|}
\hline \multicolumn{2}{|c|}{ Analysis } \\
\hline $\begin{array}{l}\text { Casing radius: } \\
\text { Screen length: } \\
\text { Well radius: }\end{array}$ & $\begin{array}{r}0.1 \mathrm{ft} \\
4.0 \mathrm{ft} \\
0.375 \mathrm{ft}\end{array}$ \\
\hline $\begin{array}{c}\text { Static water level } \\
\text { Shut-in water levels } \\
\text { Zone }\end{array}$ & 63.53 \\
\hline Upper & 63.67 \\
\hline Middle & 63.20 \\
\hline Lower & 62.85 \\
\hline
\end{tabular}

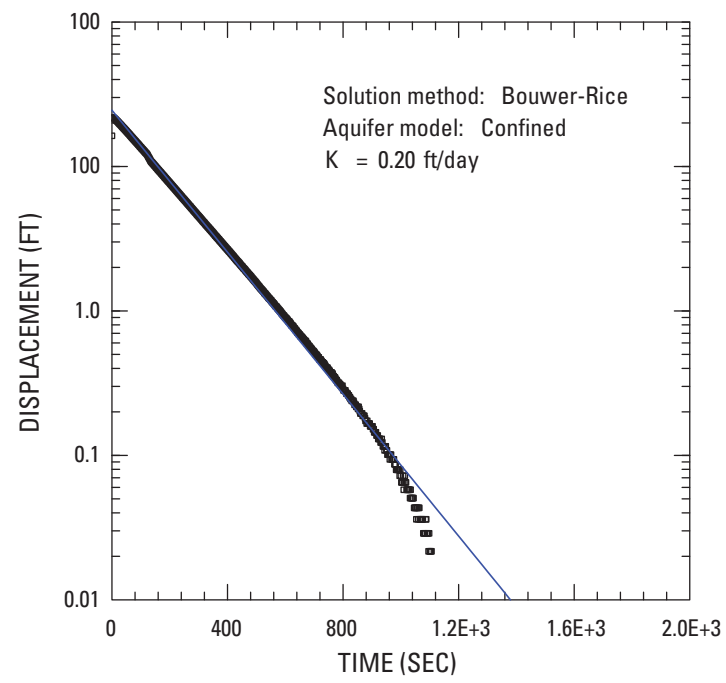

Figure 8. Test data and analysis for packer-slug test of depth interval 698-702 feet in well HAAF 11 (360392), Hunter Army Airfield, Georgia, conducted on June 25, 2009. 


\section{2- to 806-Foot and 812- to 816-Foot Tests}

The fifth and sixth slug tests were completed at depth intervals of $802-806 \mathrm{ft}$ and $812-816 \mathrm{ft}$ across beds of lower permeability within the Lower Floridan aquifer. For these intervals, the 5.8-gal slug introduced into the isolated interval through the drill stem caused an initial water-level displacement of $10 \mathrm{ft}$ and $12 \mathrm{ft}$, respectively, with rapid decay of the water level back to within $0.01 \mathrm{ft}$ of the initial water level within about 3 minutes for each test (figs. 9, 10). Straight-line fits on the semi-logarithmic plots produced calculated horizontal hydraulic conductivities of 1.7 and $1.2 \mathrm{ft} / \mathrm{d}$, respectively.

Water levels in the upper interval for each test were steady throughout the test, indicating no observable leakage during slug injection or decay. The water level in the lower zone was not monitored because the pressure exceeded the transducer's calibrated pressure range and, thus, could not be reported. Total water-level displacement across the interval could not be calculated. The water-level differences between the test interval and the upper interval still remained positive, suggesting upward flow gradients across the two depth intervals.

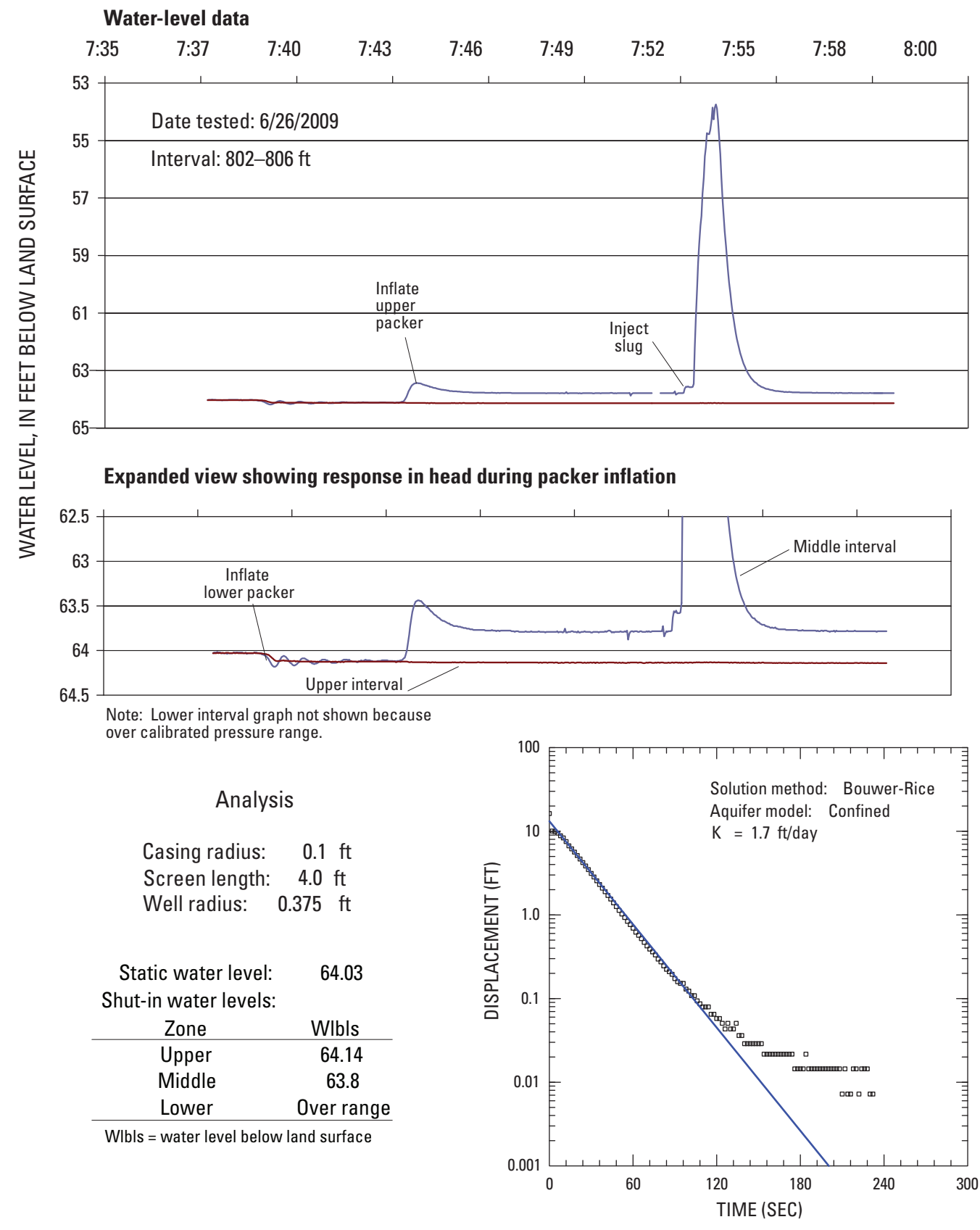

Figure 9. Test data and analysis for packer-slug test of depth interval 802-806 feet in well HAAF 11 (360392), Hunter Army Airfield, Georgia, conducted on June 26, 2009. 


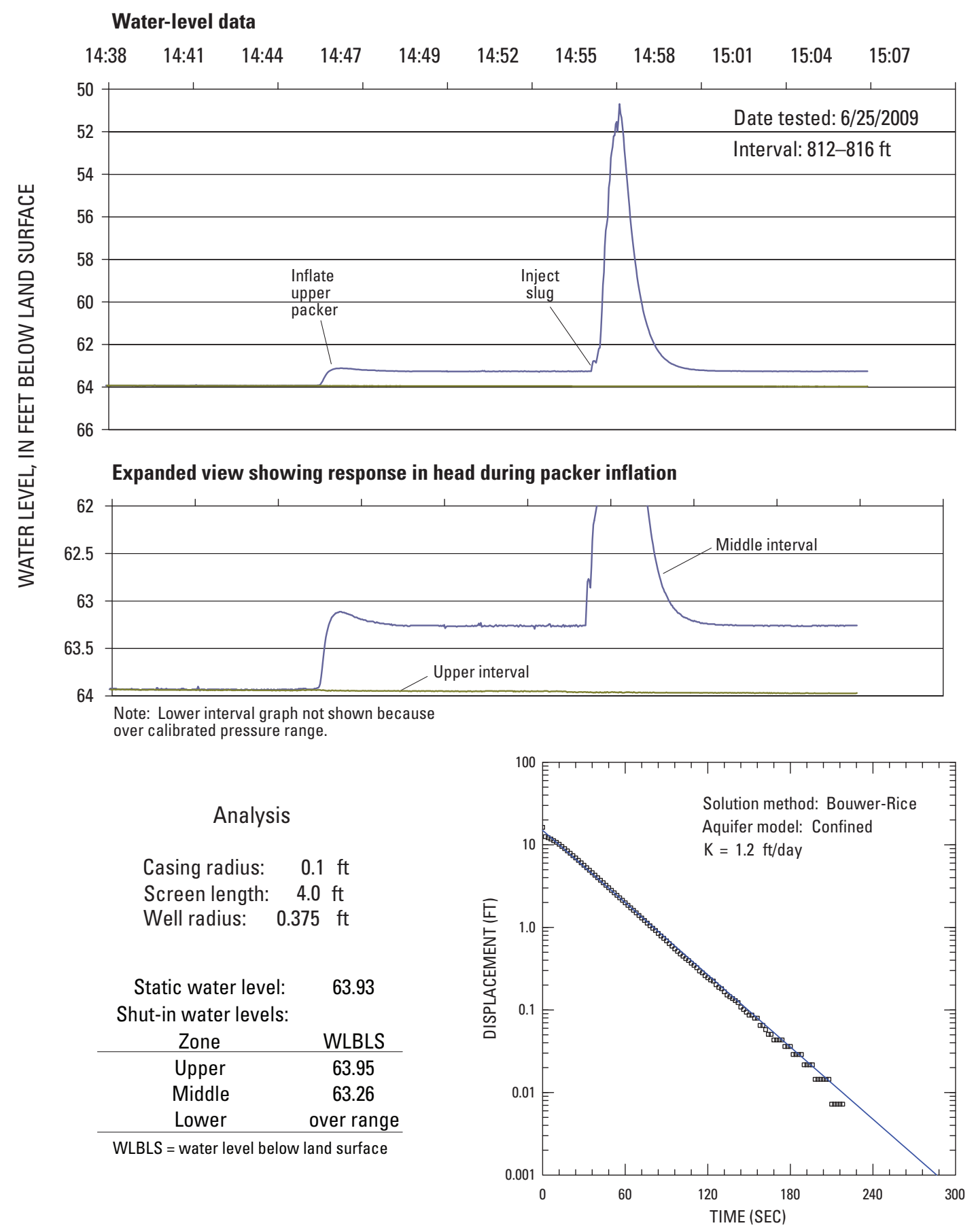

Figure 10. Test data and analysis for packer-slug test of depth interval 812-816 feet in well HAAF 11 (360392), Hunter Army Airfield, Georgia, conducted on June 25, 2009. 


\section{Aquifer Testing}

Aquifer tests were conducted at HAAF to estimate transmissivity of the Upper and Lower Floridan aquifers and storage coefficient of the Upper Floridan aquifer. Details on these tests are provided in subsequent sections, and results are summarized in table 3. Site layout and a schematic diagram showing hydrogeologic units and open intervals in the wells are shown in figure 11.

An important factor in the analysis of water-level data in the vicinity of HAAF is filtering out interferences that can create water-level fluctuations that may obscure relatively small drawdown response. Major interferences include tidal fluctuations, barometric pressure changes, and local and regional pumping effects. Halford (2006) developed a procedure to filter out interferences by use of simple models for estimating unpumped water levels that are referred to as synthetic water levels. These models sum multiple time series, such as barometric pressure, tidal potential, and background water-level trends, to simulate non-pumping water levels. The procedure involves adjustment of the amplitude and phase of each time series so that synthetic water levels match measured water levels during periods unaffected by an aquifer test. Differences between synthetic and measured water levels are minimized with a sum-of-squares objective function. This procedure was applied to water levels for each of the aquifer tests conducted at HAAF.

Table 3. Summary of transmissivity and storage cofficients determined from aquifer tests conducted in the Upper and Lower Floridan aquifers, Hunter Army Airfield, Chatham County, Georgia, 2009.

$\left[\mathrm{ft}^{2} / \mathrm{d}\right.$, square foot per day; - , not applicable]

\begin{tabular}{|c|c|c|c|c|c|}
\hline \multirow[b]{2}{*}{ Test location } & \multirow[b]{2}{*}{ Hydrologic unit } & \multirow[b]{2}{*}{ Dates tested } & \multicolumn{2}{|c|}{ Coefficents } & \multirow[b]{2}{*}{ Remarks } \\
\hline & & & $\begin{array}{c}\text { Transmissivity } \\
\left(\mathrm{ft}^{2} / \mathrm{d}\right)\end{array}$ & $\begin{array}{c}\text { Storage } \\
\text { (dimensionless) }\end{array}$ & \\
\hline
\end{tabular}

\begin{tabular}{|c|c|c|c|c|c|}
\hline $\begin{array}{l}\text { HAAF } 9 \\
\qquad(36 Q 391)\end{array}$ & Upper Floridan & $8 / 10 / 2009$ & 41,000 & $2.28 \mathrm{E}-4$ & $\begin{array}{l}\text { Repeat of } 2 / 17-18 / 2009 \text { test using a } \\
\text { slightly lower pumping rate. Used } \\
\text { Hantush, } 1960 \text {, leaky aquifer solution. } \\
\text { Drawdown was corrected for tidal and } \\
\text { other fluctuations prior to analysis. }\end{array}$ \\
\hline $\begin{array}{l}\text { HAAF } 11 \\
\qquad(36 \text { Q392) }\end{array}$ & Lower Floridan & $8 / 13-16 / 2009$ & $\begin{array}{l}10,000 \text { from } \\
\text { drawdown data; } \\
12,000 \text { from } \\
\text { recovery data }\end{array}$ & - & $\begin{array}{l}\text { Single well test conducted upon } \\
\text { completion of Lower Floridan well } \\
\text { open from } 703-1,100 \text { feet. Analysis } \\
\text { used Theis, 1935, solution. Drawdown } \\
\text { was corrected for tidal and other } \\
\text { fluctuations prior to analysis. }\end{array}$ \\
\hline $\begin{array}{l}\text { HAAF } 11 \\
\qquad(36 Q 392)\end{array}$ & $\begin{array}{l}\text { Upper and Lower } \\
\text { Floridan }\end{array}$ & $6 / 19 / 2000$ & $\begin{array}{l}50,000 \text { from } \\
\text { drawdown data; } \\
49,000 \text { from } \\
\text { recovery data }\end{array}$ & - & $\begin{array}{l}\text { Single well test conducted during flow- } \\
\text { meter survey. Both the upper and lower } \\
\text { Floridan aquifer open to borehole during } \\
\text { test; well open from } 333 \text { to } 1,164 \text { feet. }\end{array}$ \\
\hline
\end{tabular}




\section{Upper Floridan Aquifer Tests}

Multi-well aquifer tests were conducted in Upper Floridan aquifer wells on February 17-18, 2009, and August 12, 2009. For each test, well HAAF 9 was pumped, and water levels in well HAAF 8 were observed (fig. 11; table 3). Well HAAF 8 is located 2,020 ft southwest of the pumped well (well HAAF 9). Well HAAF 9 was drilled in 2004 (replacing an older well at that same location) and is currently used as a water supply to support operation activities in this area of the base (Stanley Thomas, U.S. Department of the Army, Ft. Stewart, written commun., 2009). This well is operated intermittently, depending on water-supply needs. Under normal backpressure conditions, well HAAF 8 is pumped at a rate of $400-470 \mathrm{gal} / \mathrm{min}$ for several hours at a time until demand is reduced and the nearby water storage tank is brought to full capacity. Well HAAF 8 is used mostly as a supplemental supply during times of high demand and also when well HAAF 9 is being serviced.

Well construction information for wells HAAF 8 and HAAF 9 is provided in table 1 and illustrated in figure 11. Both wells are open to the Upper Floridan aquifer; however, both wells partially penetrate the confining unit. Because both the pumping and observation wells are only open to the upper portion of the Upper Floridan aquifer, the effects of partial penetration were considered in the test analysis.

\section{Analytical Method}

For each Upper Floridan aquifer test, aquifer properties were estimated using drawdown data from the observation well only; no aquifer properties were estimated from the pumped well because of partial-penetration effects. The Hantush (1960) leaky aquifer solution was selected for the analysis because this solution most closely matches aquifer site conditions compared to other analytical solutions provided in AQTESOLVTM. This solution assumes that (1) the aquifer is infinite in areal extent, homogeneous, and isotropic, (2) the pumping well is fully or partially penetrating, and flow to the pumping well is horizontal, (3) the aquifer is leaky, and flow is unsteady, (4) water is released from storage instantaneously, (5) the diameter of the pumping well is very small, and the storage in the well can be neglected, (6) the confining bed is infinite in areal extent and has a uniform vertical hydraulic conductivity and thickness, (7) the confining bed has an adjacent constant-head source, and (8) flow in the confining bed is vertical. While all of these conditions are not perfectly met at this test site, this model most closely matches actual field conditions and for this reason was selected for use in the analysis. The Hantush-Jacob (1955) solution also was evaluated; however, because it does not take into account storage in the confining layer, it was not believed to be the best method for determining the aquifer coefficients for the Upper Floridan aquifer at this test site.

\section{A. Aquifer test layout}

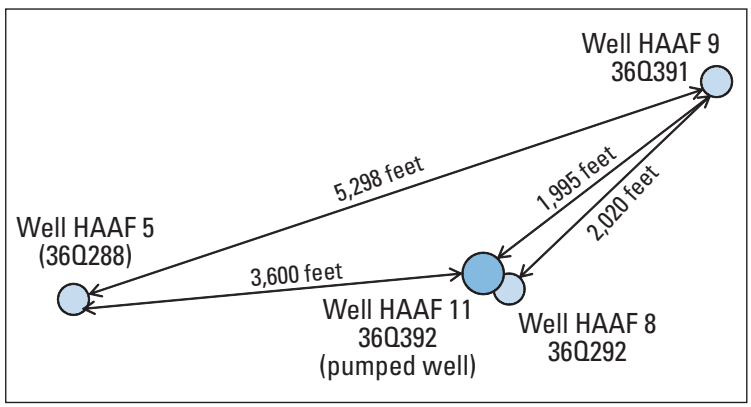

Note: Distance between well HAAF 11 and well HAAF 8 is 176 feet

\section{B. Schematic cross section}

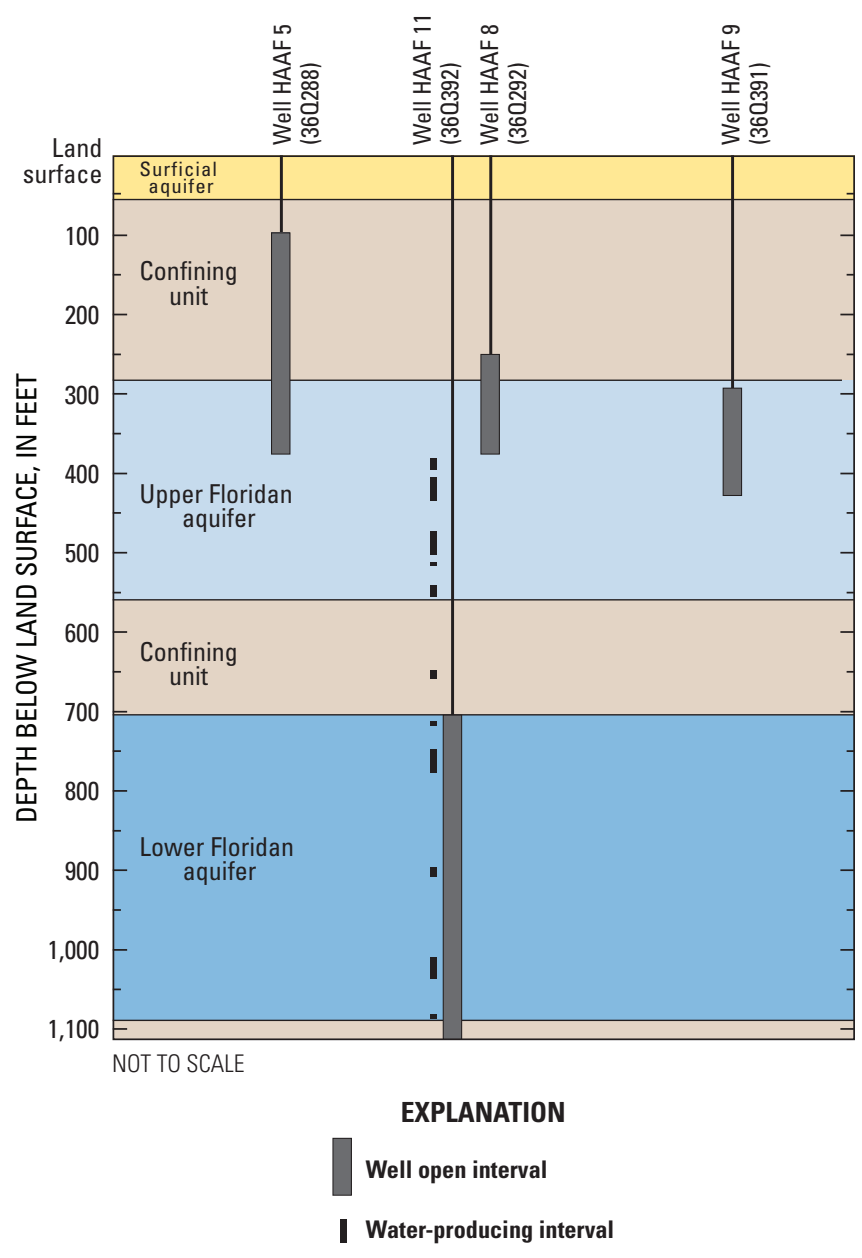

Figure 11. Location and construction characteristics of wells used for aquifer tests at Hunter Army Airfield, Chatham County, Georgia. (A) Map showing aquifer test layout, $(B)$ Schematic section showing the open intervals of the wells in relation to major hydrogeologic units. 


\section{Test 1: February 17-18, 2009}

The first Upper Floridan aquifer performance test was conducted on February 17-18, 2009, using well HAAF 9 as the pumping well. Pressure transducers and manual waterlevel measurements were used to monitor water levels during the aquifer test. The production and observation wells were monitored from February 12, 2009, through February 24, 2009, which encompassed a pre-test background period of 5 days and post-test monitoring of 6 days. The post-test monitoring record for well HAAF 9 is not included in the dataset because the wireless data logger used in this well became lodged and could not be retrieved following the conclusion of the test. Manual measurements, therefore, are used for the pumped well.
Well HAAF 9 was pumped for 24 hours starting on February 17, 2009, at 1:40 PM EST and stopping on February 18, 2009 , at 1:41PM EST. Cumulative pumpage during this period was $621,000 \mathrm{gal}$ with an average pumping rate of $430 \mathrm{gal} / \mathrm{min}$ during the 24-hour test. Because this well was operated against water-system pressure, the pumping rate varied slightly throughout the test (fig. 12). The largest variations occurred within the first hour of pumping; pumping then stabilized between 428 and $435 \mathrm{gal} / \mathrm{min}$. During a 40 -minute period on February 17, 2009, at 9:00 PM EST, pumping temporarily dropped to $400 \mathrm{gal} / \mathrm{min}$ in response to a pressure change in the system. Following pump shutdown, well HAAF 9 was kept offline for the remainder of the monitoring period to observe background fluctuations.

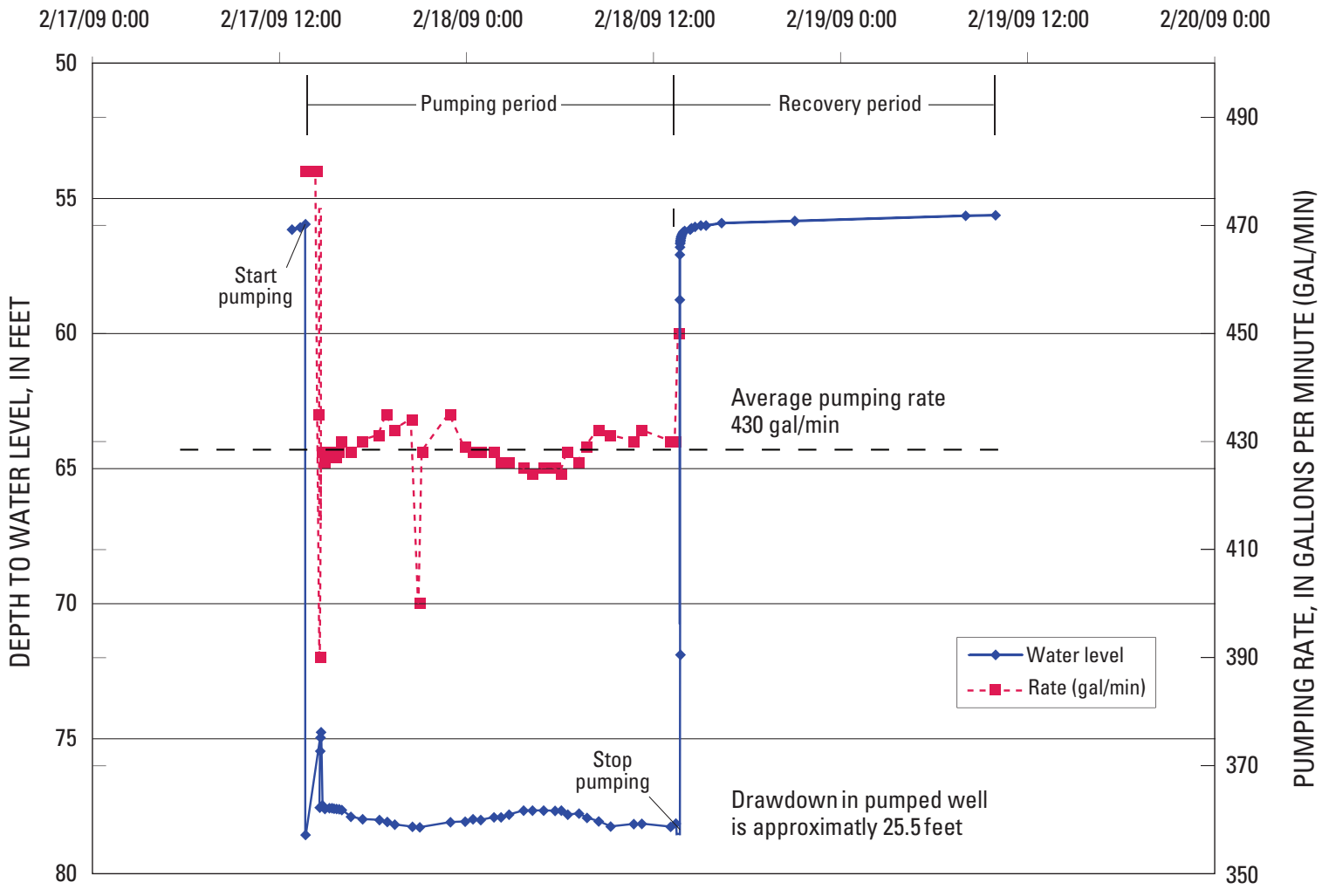

Figure 12. Water-level data for well HAAF 9 (360391) during 24-hour aquifer test conducted February 17-18, 2009, Hunter Army Airfield, Chatham County, Georgia. 
The hydrograph for well HAAF 8 shows barometric and tidally influenced fluctuations similar to that observed in the background monitoring well (fig. 13). The larger-scale fluctuations on the hydrographs are attributed to barometric-pressure changes, and smaller cyclic fluctuations are in response to changes in tidal stage. An influence of nearby pumping and the regional water-level trend can be seen in the hydrograph for well HAAF 8. These external influences tended to mask the drawdown response related to the pumping well alone and were filtered out of the raw data prior to aquifer-test analysis. The process of correcting water-level data to determine the pumping-induced drawdown estimates is described below.

\section{Drawdown Estimation}

Using the filtering spreadsheet provided by Halford (2006), the amplitude and phase of each time series (background, tide, barometric pressure) were adjusted to create a composite synthetic water-level hydrograph spanning the period of the test. Adjustments to these individual time series were made to minimize the differences between synthetic and measured water levels. Estimated pumpage-induced drawdowns were then derived from differences between measured and synthetic water levels during pumping and recovery periods.

The effect of each time series on the development of a synthetic water level for the aquifer test was determined by using a trial-and-error approach, adding each component sequentially and then evaluating the effect of that series on the filtering process. Several components were combined and then the components that improved the fit were eventually used in the final filtering process. Representative time series and the effects on the filtering process are shown in figure 14.

Using the background water-level time series alone yielded a root-mean-square (RMS) of $0.0432 \mathrm{ft}$ and a relatively poor fit to the tidal-loading effects (fig. 14A). Using a 6-hour moving average of the background time series, the fit improved, but still showed obvious effects of tidal loading that were not removed (fig. 14B). Combining the raw background time series with the 6-hour moving average greatly improved the fit, reducing differences between the synthetic and observed water levels down to an RMS of $0.0270 \mathrm{ft}$ (fig. 14C).

Adding the barometric pressure time series to the analysis slightly improved the fit down to an RMS of $0.0263 \mathrm{ft}$ (fig. 14D). Attempts were made to use barometric pressure alone, without any other time series, but were unrealistic, failed to improve the fit, and are not shown here. Similar attempts were made using the tidal stage time series alone, but this did not produce satisfactory results. Combining tidal stage and barometric pressure time series, however, did provide a fairly good fit, giving an RMS of $0.0386 \mathrm{ft}$ (fig. 14E).

Finally, all of the time series were combined, including the raw and 6-hour moving-average time series from background well 36Q020, tidal stage, barometric pressure, gravity tides, and earth tides. This combination created a composite synthetic water level that yielded the lowest RMS of $0.0138 \mathrm{ft}$, the best fit of all of the various combinations attempted during the filtering procedure (fig. 14F).
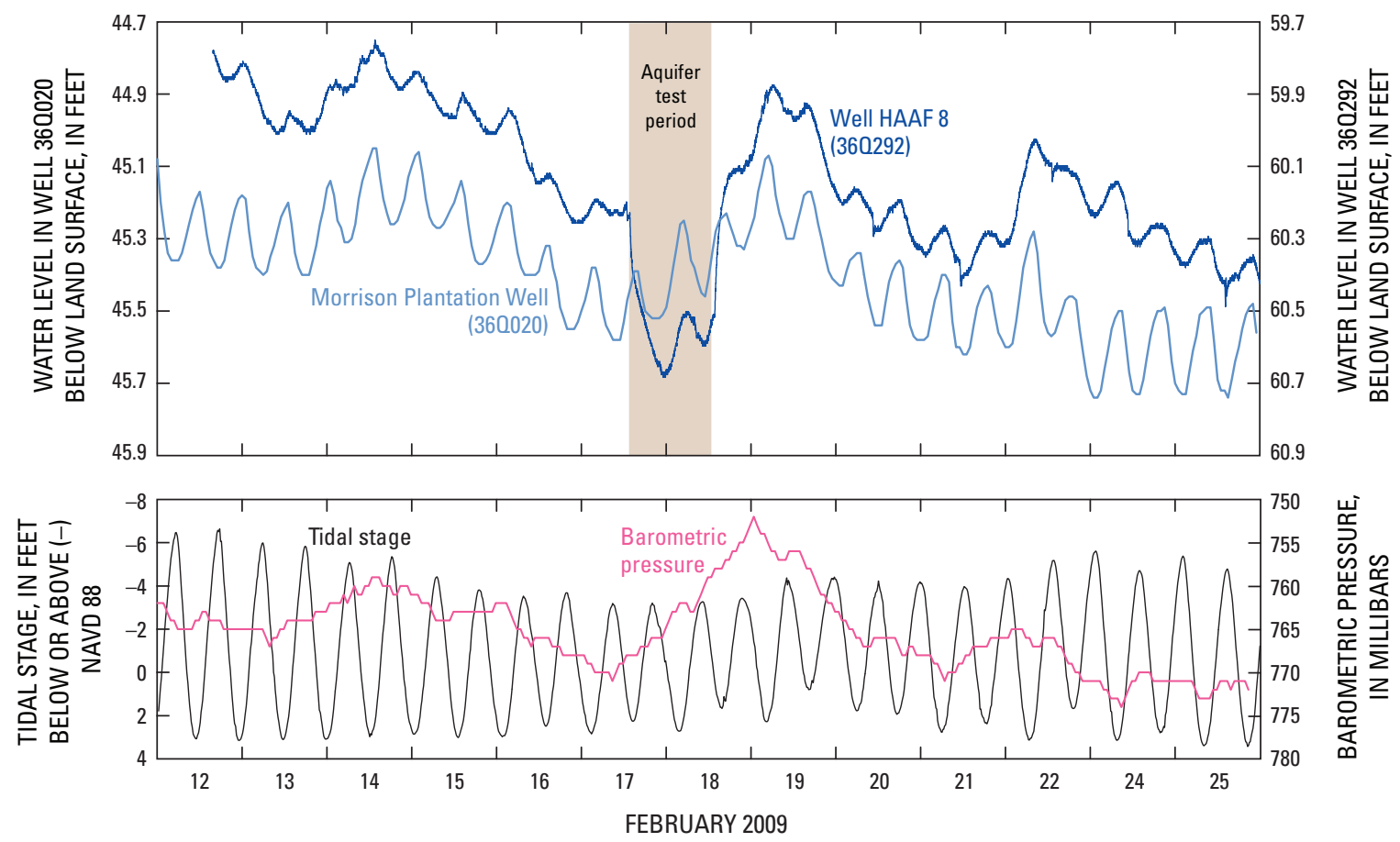

Figure 13. Comparison of water levels at well HAAF 8 (360292) to background water levels at Morrison Plantation observation well (360020) and to stage and barometric pressure at tidal gage 021989773 (U.S. Army Corps of Engineers Dock, Savannah, Georgia), Hunter Army Airfield, Chatham County, Georgia, February 12-26, 2009. 


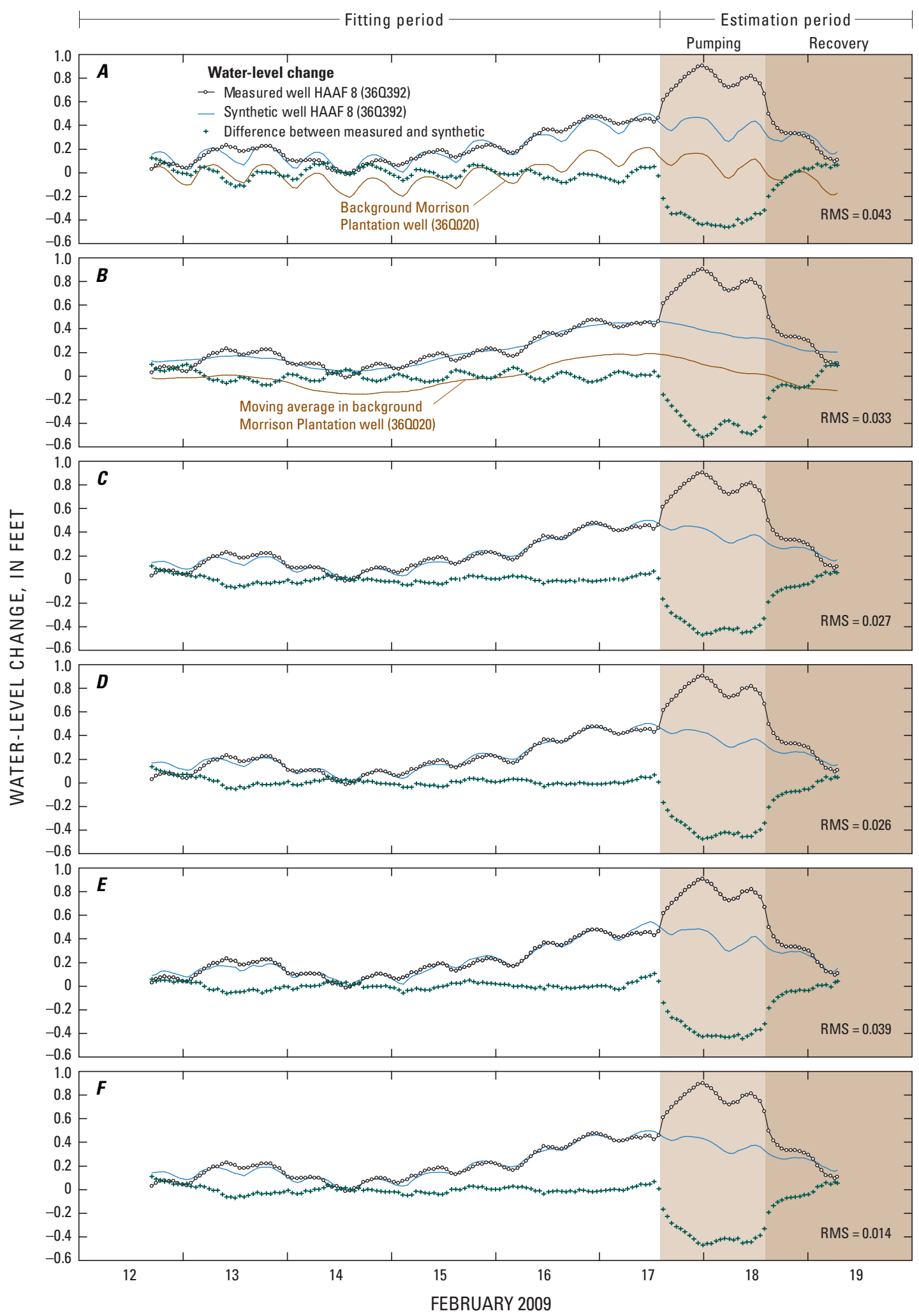

Figure 14. Effects of different time series components on development of a synthetic water level used to filter out extraneous trends for well HAAF 8 (360292), Hunter Army Airfield, Chatham County, Georgia. (A) raw waterlevel data for Morrison Plantation well 360020, (B) 6-hour moving average water level for well 360020, (C) raw and 6-hour moving average water-level data for well 360020, (D) raw and 6-hour moving-average water level for well 360020 and barometric pressure, (E) raw barometric pressure and raw tidal stage data, and (F) raw and 6-hour moving average water-level data for well 360020, tidal stage, barometric pressure, gravity tides, and earth tides. [RMS, root mean square of differences between measured and synthetic water levels] 


\section{Summary of Hydrologic Testing of the Floridan Aquifer System at Hunter Army Airfield, Chatham County, Georgia}

\section{Aquifer-Test Analysis}

The resulting logarithmic plot of drawdown data for observation well HAAF 8 showed a response that is characteristic of a leaky artesian aquifer with storage of water in the semiconfining bed (fig. 15). In particular, the late-time data did not fit the Theis (1935) type curve of an ideal confined aquifer. The flattening of the curve after approximately 40 minutes indicates appreciable amounts of water are being released from storage, probably from the underlying semiconfining layer and the Lower Floridan aquifer.
Using the Hantush (1960) solution, acceptable curve matches were obtained by using combinations of the leakance terms $r / B^{\prime}$ and $\beta$ and varying the storativity within a reasonable range of values. The early time data, from 3 to 300 minutes, matched fairly well to the solution, while the latter part of the measured field data departed from the type curve (shifted upward), possibly due to a nearby pumping influence of well HAAF 9. The best match with the Hantush (1960) analysis gives a transmissivity of 40,000 feet squared per day $\left(\mathrm{ft}^{2} / \mathrm{d}\right)$ and a storage coefficient of 0.00025 (fig. 15).

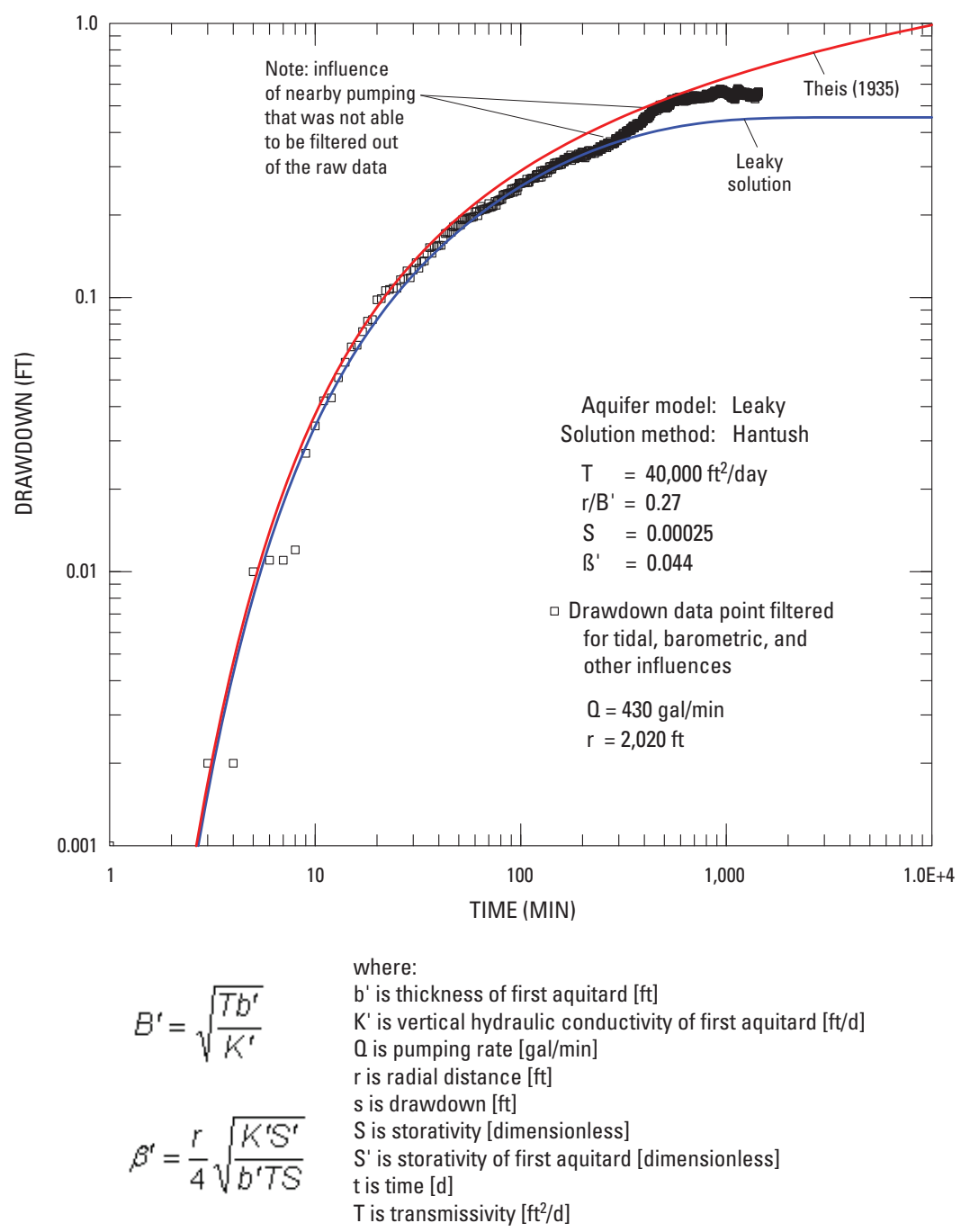

Figure 15. Logarithmic plot of drawdown and time for observation well HAAF 8 (360292) located 2,020 feet from pumping well HAAF 9 for Upper Floridan aquifer test conducted February 17-18, 2009, Hunter Army Airfield, Chatham County, Georgia. 


\section{Test 2: August 10, 2009}

A second multi-well Upper Floridan aquifer performance test was conducted on August 10, 2009, during the first stage of the Lower Floridan aquifer test, using well HAAF 8 as the test observation well. This test was designed in a similar manner as the previous test. Well HAAF 9 was pumped at an average rate of $400 \mathrm{gal} / \mathrm{min}$, and drawdown was monitored at well HAAF 8, located 2,020 $\mathrm{ft}$ to the southwest of the pumped well (well HAAF 9). Pumping for this test began at 5:30 PM on August 10, 2009, and continued throughout the next day.
The analysis of this test provided additional confirmation of the aquifer-test results obtained from the previously described 24-hour test during February 17-18, 2009.

Using the same procedures described above, raw waterlevel data from well HAAF 8 were first filtered to remove the effects of barometric pressure, tidal influences, and regional trends and then analyzed with the Hantush (1960) analytical solution. The results of this analysis produced a transmissivity of 41,000 ft $\mathrm{ft}^{2} / \mathrm{d}$ and a storage coefficient of 2.3E-04 (fig. 16). These results are a close match to the values determined from the first aquifer performance test described above.

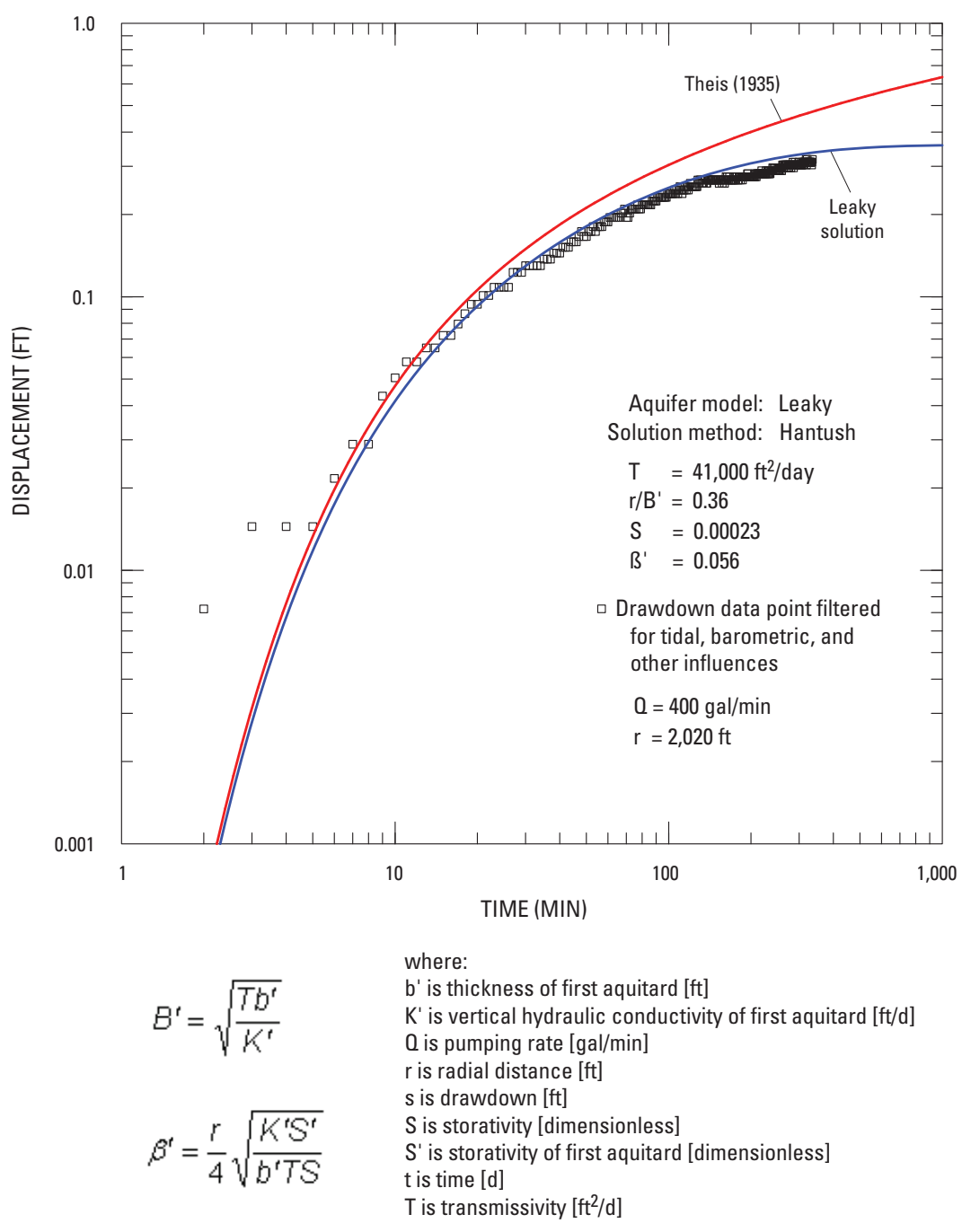

Figure 16. Logarithmic plot of drawdown and time for observation well HAAF 8 (360292) located 2,020 feet from pumping well HAAF 9 for Upper Floridan aquifer test conducted August 12, 2009, Hunter Army Airfield, Chatham County, Georgia. 


\section{Lower Floridan Aquifer Test: August 13-16, 2009}

A 72-hour aquifer performance test was completed August 13-16, 2009, to estimate the transmissivity of the Lower Floridan aquifer and to document pumping-induced drawdown in the Upper Floridan aquifer. Although the analysis of this test was treated as a single-well test with only the transmissivity of the pumped well being estimated, drawdown data from the Upper Floridan observation wells were collected so that leakage could be simulated in the numerical model (not presented here). The pumped well fully penetrates the entire thickness of the Lower Floridan aquifer, with an open interval from $703 \mathrm{ft}$ to 1,112 ft. Upper Floridan aquifer observation wells are located $176 \mathrm{ft}$ to the southeast (well HAAF 8), 1,995 ft to the northeast (well HAAF 9), and $3,600 \mathrm{ft}$ to the west (well HAAF 5; fig. 11). Well-construction information is provided in table 1 , and a site layout and a schematic diagram showing hydrogeologic units and well open intervals are shown in figure 11.

\section{Test Procedure}

Because of the length of time that was anticipated to complete the Lower Floridan aquifer test, HAAF required that Upper Floridan aquifer well HAAF 9, which is located 2,020 ft from the new Lower Floridan aquifer well, be kept operational to supply water to this part of the base during the test. To minimize the effects of the nearby pumping on the aquifer test, a continuous constant-rate pumping schedule was maintained for HAAF 9, starting 2 days before the start of the aquifer test and continuing throughout the duration of the test.
Background water levels were monitored in well 36Q020 located at Morrison Plantation west of HAAF (fig. 1). Tidal stage and barometric pressure were monitored at USGS tidal gage station 021989773 located at the U.S. Army Corps of Engineers Dock in Savannah, Georgia. These data were used to filter out background fluctuations and estimate pumpinginduced drawdown in the two observation wells.

All of the wells used in this test, including the two pumped and two observation wells, were monitored with pressure transducers beginning July 30, 2009, and ending September 2, 2009. This period encompassed 11 days of pretest background monitoring and 12 days of post-test monitoring. Manual water-level measurements were made periodically in the pumped and observation wells. The major stages/events during the test included:

- Pre-test monitoring began on July 30, 2009

- Startup of well HAAF 9 (400 gal $/ \mathrm{min})$ at August 10, 2009 5:07 PM EST

- Temporary shutdown of well No 9 at August 11, 2009 9:04 PM EST

- Restart of well HAAF 9 (400 gal $/ \mathrm{min})$ at August 12, 2009 10:05 AM EST

- Startup of well HAAF 11 (754 gal/min) at August 13, 2009 9:10 AM EST

- At well HAAF 11, the generator stalled for 1 minute, and flow readjusted ( $747 \mathrm{gal} / \mathrm{min}$ ) at August 14, 2009 1:12 AM EST

- Shutdown of well HAAF 11 at August 16, 2009 9:09 AM EST 
- Shutdown of well HAAF 9 at August 21, 2009 10:01AM EST

- Post-test monitoring ends and transducers were pulled on September 2, 2009

Cumulative pumpage for well HAAF 11 was 3.23 million gallons with an average pumping rate of $747 \mathrm{gal} / \mathrm{min}$ during the 72 -hour test. Other than one slight adjustment as a result of a temporary mechanical issue that lasted for 1 minute, the pumping rate remained relatively constant throughout the duration of the 72-hour test. The pumping rate at well HAAF 9 averaged $400 \mathrm{gal} / \mathrm{min}$ with a fluctuation of $10-15 \mathrm{gal} / \mathrm{min}$ in response to pressure changes in the HAAF water system at various times of the day.

During the 72-hour test, a drawdown response was observed in the Upper Floridan aquifer wells (fig. 17). The water level in well HAAF 8, located $176 \mathrm{ft}$ from the pumping well, began drawing down within approximately 1 hour of the start of the pumping test. Drawdown in well HAAF 5, located $3,600 \mathrm{ft}$ away, was less evident because of the decreasing water-level trend at the beginning of the test. Barometric pressure changes, tidal fluctuations, and regional water-level trends all combined to partially mask the pumping-induced drawdown in observation well HAAF 5.
Well HAAF 11 (360392)

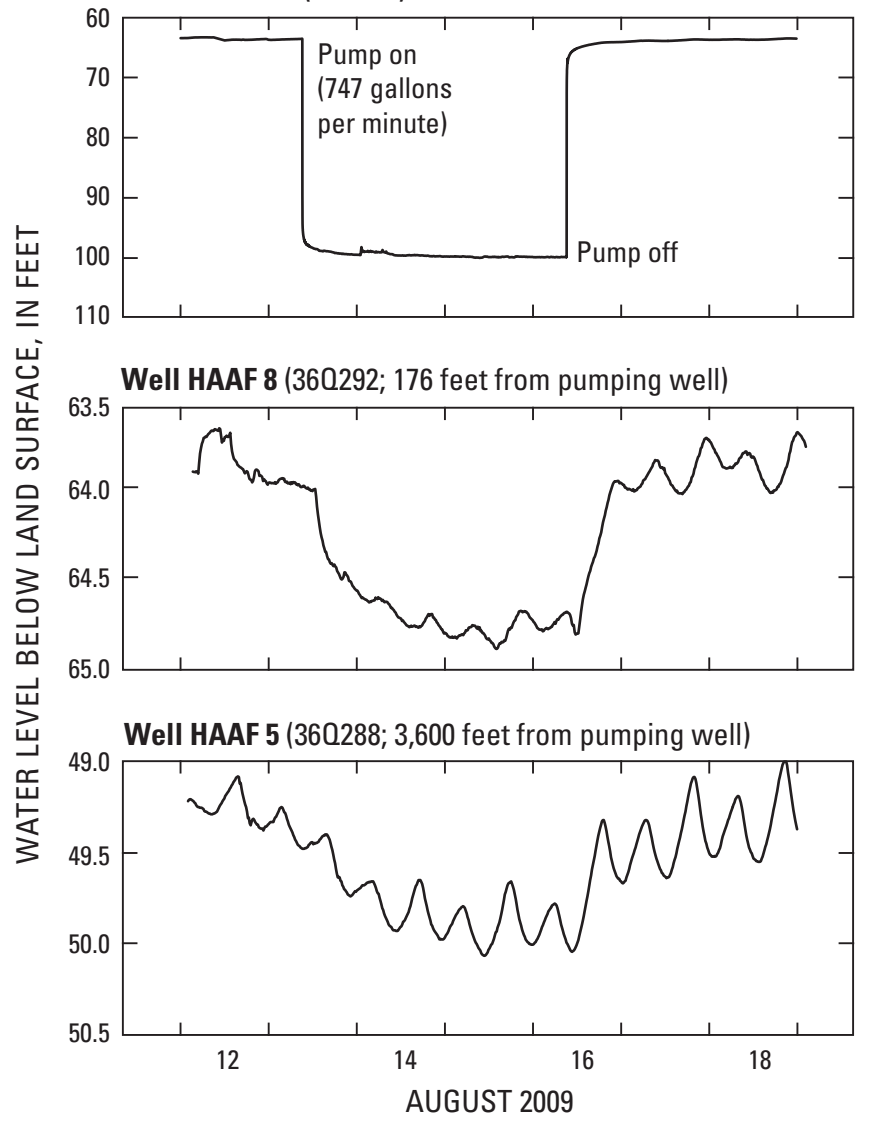

Figure 17. Drawdown response in Upper Floridan wells HAAF 8 (360292) and HAAF 5 (360288) during a 72-hour aquifer test of Lower Floridan well HAAF 11 (360392) conducted August 13-16, 2009, Hunter Army Airfield, Chatham County, Georgia. 


\section{Drawdown Estimation}

The effects of background water-level trends, barometric pressure, and tidal loading were removed from the raw waterlevel data series using the Halford (2006) filtering spreadsheet method. The amplitude and phase of each time series were adjusted to create a composite synthetic water-level hydrograph spanning the period of the test. Estimated pumpageinduced drawdowns were then derived from the differences between measured and synthetic water levels during the pumping and recovery periods. This process was applied only to wells HAAF 11, HAAF 5, and HAAF 8. Variations in the pumping rate at well HAAF 9 caused water levels to fluctuate greater than pumping-induced drawdown; therefore, this well was excluded from the analysis.

The raw water-level hydrographs from the 72-hour Lower Floridan aquifer test and the response at the two Upper Floridan aquifer observation wells are shown in figure 17. Even without filtering, pumping-induced drawdown at well HAAF 8 is evident in the hydrograph while the drawdown in well HAAF 5 is less evident, but distinguishable.
The effects of pumping well HAAF 9 on water levels in the area were included in the filtering process. To accommodate this effect, the fitting period for filtering was expanded to encompass 1 week before and 2 weeks after the test was completed (fig. 18). For well HAAF 8, synthetic and measured water levels matched fairly well during the week prior to starting to pump well HAAF 9 (fig. 18A). During this pretest period, well HAAF 9 was taken offline to obtain natural background fluctuations. Pumping from well HAAF 9 was started 2 days prior to the startup of the aquifer test and was maintained at an average pumping rate of $400 \mathrm{gal} / \mathrm{min}$ until 5 days following the end of the Lower Floridan aquifer test. The drawdown and recovery response of pumping both wells HAAF 9 and HAAF 11 is shown in figure $18 A$. After removing the pumping effects for well HAAF 9, the total drawdown and recovery response attributed to well HAAF 11 pumping alone was estimated to be $0.76 \mathrm{ft}$ (fig. 18A, lower graph). At well HAAF 5, located 3,600 ft away from the Lower Floridan well, the total pumping-induced drawdown attributed to well HAAF 11 pumping was estimated to be $0.32 \mathrm{ft}$ (fig. $18 B$, lower graph). 


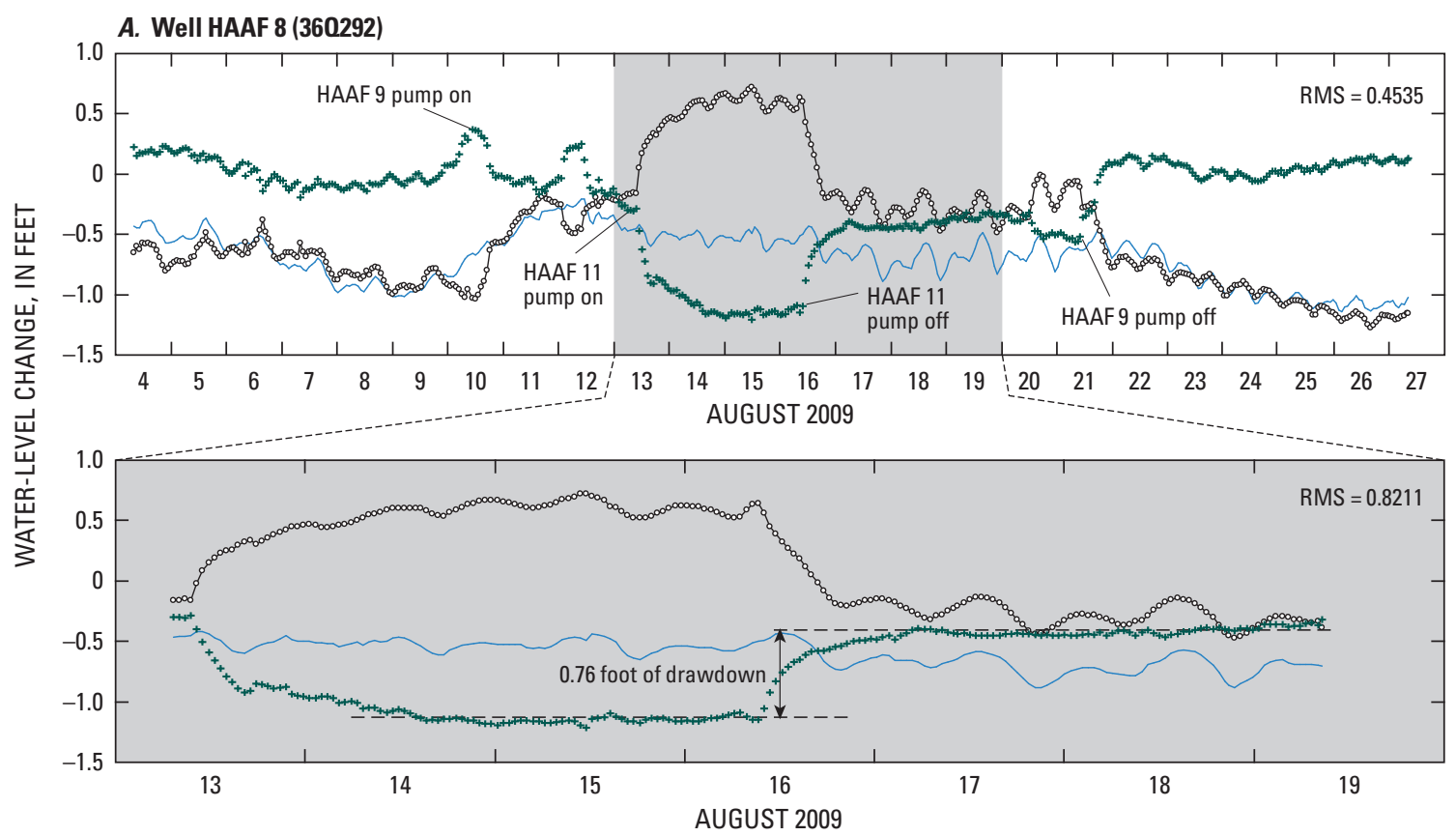

B. Well HAAF 5 (360288)

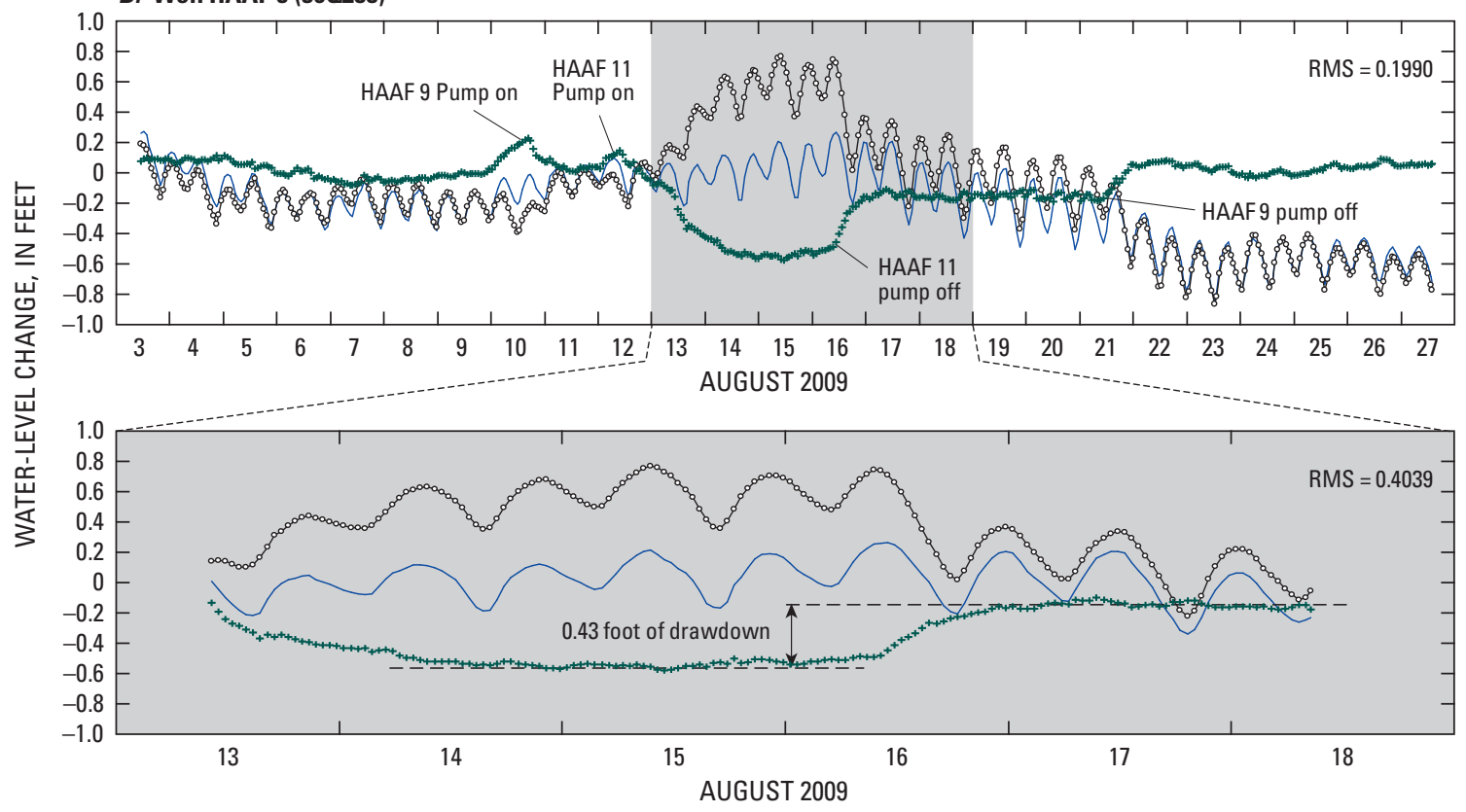

EXPLANATION

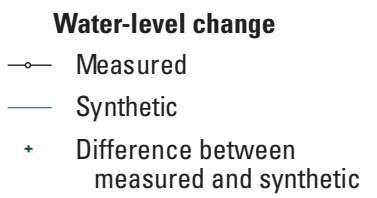

Figure 18. Estimated drawdown in Upper Floridan aquifer wells (A) HAAF 8 (360292) and (B) HAAF 5 (360288) during a 72-hour aquifer test of Lower Floridan well HAAF 11 (360392) conducted August 13-16, 2009, Hunter Army Airfield, Chatham County, Georgia. 


\section{Aquifer-Test Analysis}

The transmissivity of the Lower Floridan aquifer was estimated from the drawdown and recovery data obtained from the pumped well (well HAAF 11) because no other nearby Lower Floridan wells were available for drawdown observations. Similar to the Upper Floridan aquifer tests described previously, the Lower Floridan aquifer test also shows a leaky artesian aquifer response with the flattening of the drawdown starting several hundred minutes into the test (fig. 19). The transmissivity calculated using the Theis (1935) solution was $10,000 \mathrm{ft}^{2} / \mathrm{d}$ (fig. 19A). The Theis (1935) solution assumes the aquifer has an infinite areal extent, is homogeneous and isotropic, and has a uniform thickness; the pumping well is fully penetrating; flow to the well is horizontal; the aquifer is confined; flow is unsteady and water is released instantaneously from storage with decline of hydraulic head; and the effects of borehole storage are small enough to be neglected. Because of these assumptions (and the observed leakage response), the type curve was only matched to early-time data between 7 and 90 minutes. The observed values plotting below the Theis (1935) curve between 1 and 7 minutes were attributed to borehole storage, and these time-series data were included in this analysis.

The Theis (1935) solution for recovery data in a confined aquifer was also used to calculate transmissivity for the aquifer test. In the Theis recovery method, the residual drawdown is plotted against $\mathrm{t} / \mathrm{t}$ ' (time over elapsed time since pumping began) on a semi-logarithmic plot (fig. 19B). A straight-line fit through the observed residual drawdown produced a calculated transmissivity of $12,000 \mathrm{ft}^{2} /$ day, which is comparable to the value determined using the drawdown data. Considering the transmissivity values obtained from the pumping and recovery phases, a value of $11,000 \mathrm{ft}^{2} / \mathrm{d}$ was estimated to represent the Lower Floridan aquifer's transmissivity at this test site.
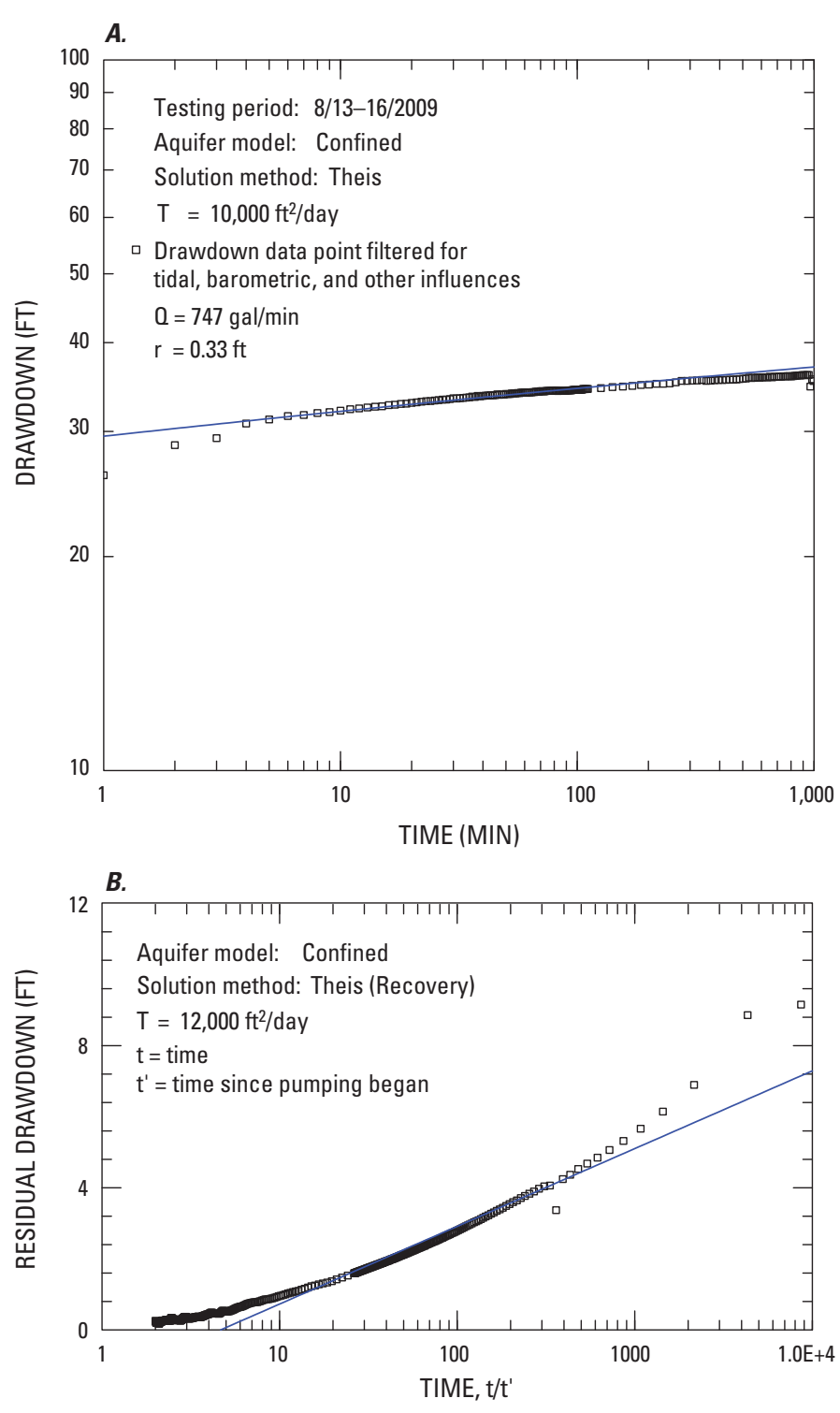

Figure 19. Aquifer-test plots for 72-hour aquifer test of Lower Floridan aquifer conducted August 13-16, 2009, Hunter Army Airfield, Chatham County, Georgia. (A) Loglog plot of drawdown and time and $(B)$ semi-logarithmic plot of residual drawdown and $t / t$ '. [Note: Storativity is not computed for single-well test] 


\section{Combined Upper and Lower Floridan Aquifer Test}

A combined Upper and Lower Floridan aquifer performance test was completed on June 19, 2009, conducted at the same time as the pumping flowmeter tests. The aquifer test provided an opportunity to obtain a transmissivity estimate for the combined aquifer system while the well was open to both aquifers. During this test, the open borehole (333-1,112 ft) of well HAAF 11 was pumped at a constant rate of $847 \mathrm{gal} / \mathrm{min}$ for 6 hours; water levels were recorded in the pumped well and in well HAAF 8. At the time of this test, the well casing in well HAAF 11 extended to $333 \mathrm{ft}$; both the Upper and Lower Floridan aquifers were open to the borehole between depths of $333 \mathrm{ft}$ and $1,112 \mathrm{ft}$. Well HAAF 8 served as an observation well; however, as shown in figure 11, this well is open only to the Upper Floridan aquifer and, therefore, was not used in the aquifer-test analysis.

The aquifer-test analysis for the combined Upper and Lower Floridan aquifers was treated as a fully penetrating single-well test of a confined aquifer system. The resulting logarithmic plot of the drawdown data for the pumping well discharging $847 \mathrm{gal} / \mathrm{min}$ indicates a response along the Theis (1935) type curve of an ideal confined aquifer (fig. 20). The small shift in the drawdown data shown in figure 18 was attributed to the startup of well HAAF 9 and was not matched for the aquifer-test analysis.

The Theis (1935) method was applied to both the drawdown and recovery periods (fig. 20) with a calculated transmissivity of 50,000 and 49,000 $\mathrm{ft}^{2} / \mathrm{d}$, respectively. Given these results, the transmissivity of the combined Upper and Lower Floridan aquifers is estimated to be $50,000 \mathrm{ft}^{2} / \mathrm{d}$.
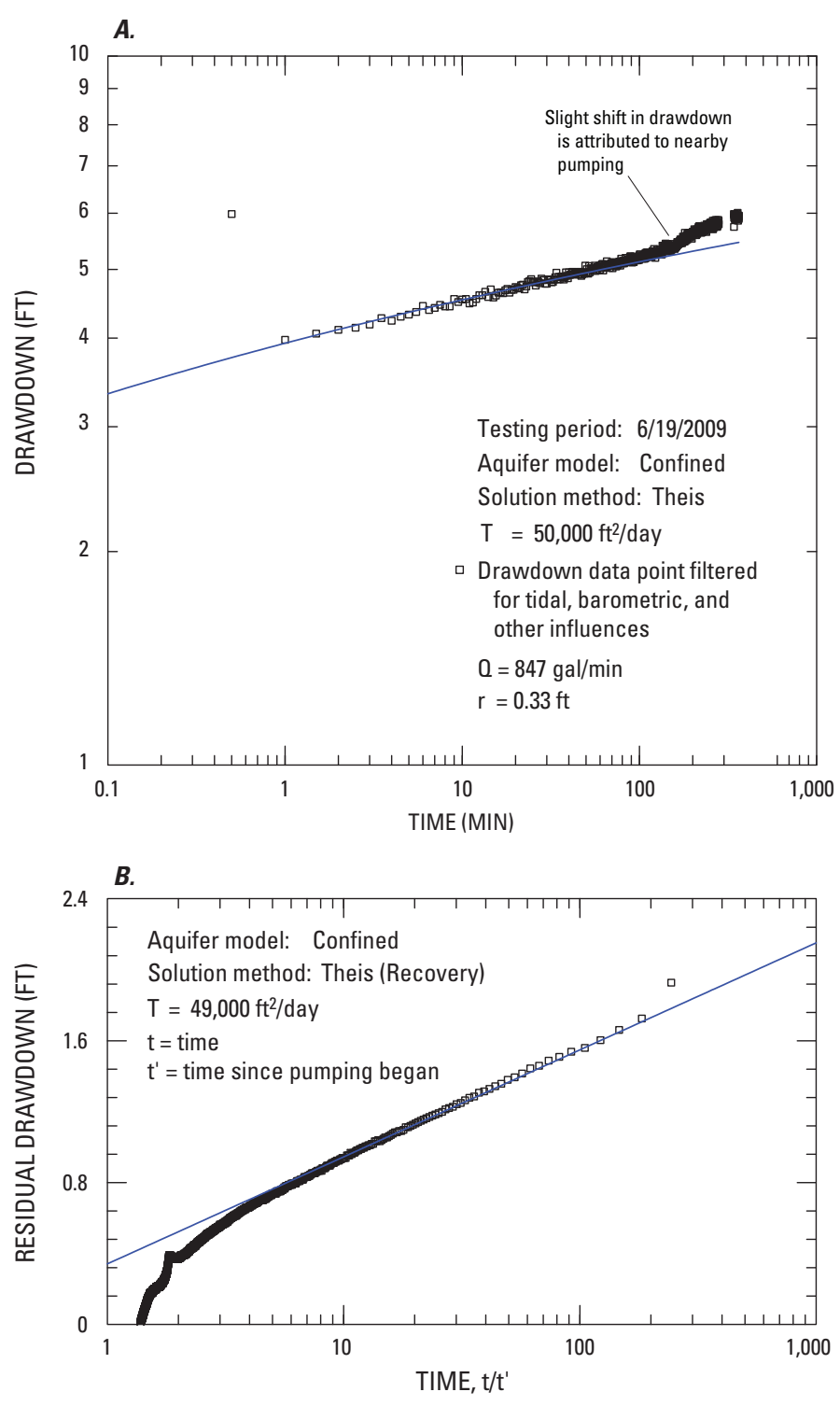

Figure 20. Aquifer-test plots for 6-hour aquifer test of combined Upper and Lower Floridan aquifers in well HAAF 11 conducted June 19, 2009, Hunter Army Airfield, Chatham County, Georgia. (A) Log-log plot of drawdown and time and $(B)$ semi-logarithmic plot of residual drawdown and $t / t$ '. [Note: Storativity is not computed for single-well test] 


\section{Summary and Conclusions}

A 1,168-foot deep test well was constructed at Hunter Army Airfield to investigate the potential of using the Lower Floridan aquifer as a source of water supply to satisfy increased needs caused by base expansion and increased troop levels. Hydrologic testing was completed to obtain data needed for development of a groundwater flow model that could be used to determine the contribution from the Upper Floridan aquifer that would result from the proposed additional withdrawal from the Lower Floridan well. The testing at this site included flowmeter surveys, packer-slug tests in the test borehole, and aquifer tests of the Upper and Lower Floridan aquifers.

Flowmeter surveys were completed at different stages of well construction to determine the depth and yield of waterbearing zones and to identify confining beds that separate the main producing aquifers. During a survey when the borehole was open to both the upper and lower aquifers, five water-producing zones were identified in the Upper Floridan aquifer that supply 83.5 percent of the total pumpage, and five water-producing zones in the Lower Floridan aquifer supply the remaining 16.5 percent. An upward gradient was indicated from the ambient flowmeter survey. Under ambient conditions, 7.6 gallons per minute of groundwater was detected entering the borehole between 750 and 1,069 feet (ft) below land surface, then moved upward, and exited the borehole into lower-head zones located between 333 and $527 \mathrm{ft}$. During a survey of the completed Lower Floridan well, six distinct water-producing zones were identified; one 17-ft-thick zone at 768-785 ft yielded 47.9 percent of the total pumpage while the remaining five zones yielded between 2 and 15 percent each.

The following aquifer characteristics were determined on the basis of evaluation of the packer-slug tests and aquifer performance tests conducted at the test site:

- The transmissivity of the Upper Floridan aquifer is estimated to be 40,000 square feet per day ( $\mathrm{ft}^{2} /$ day) based on analysis of data from two separate multiwell aquifer tests. Storativity values from these tests ranged from 0.000228 to 0.000250 .

- The transmissivity of the Lower Floridan is estimated to be $10,000 \mathrm{ft}^{2} /$ day based on analysis of drawdown and recovery data from a single-well test of the completed Lower Floridan well.

- The transmissivity of the combined Upper and Lower Floridan aquifer is estimated to be $50,000 \mathrm{ft}^{2} /$ day based on analysis of data from drawdown and recovery data collected during a flowmeter survey.

- The confining unit separating the Upper and Lower Floridan aquifers is approximately $160 \mathrm{ft}$ thick, as determined from pumping flowmeter surveys.

- Horizontal hydraulic conductivity measurements range from 0.2 to 3 feet per day (ft/d) from four separate packer-slug tests of the middle confining unit, and $2 \mathrm{ft} / \mathrm{d}$ from two separate packer-slug tests of the Lower Floridan aquifer.

\section{References}

Bouwer, H., and Rice, R.C., 1976, A slug test method for determining hydraulic conductivity of unconfined aquifers with completely or partially penetrating wells: Water Resources Research, v. 12, p. 423-428.

Clarke, J.S., Hacke, C.M., and Peck, M.F., 1990, Geology and ground-water resources of the coastal area of Georgia: Georgia Geologic Survey Bulletin 113, 106 p.

Falls, W.F., Harrelson, L.G., Conlon, K.J., and Petkewich, M.D., 2005, Hydrogeology, water quality, and water-supply potential of the Lower Floridan aquifer, coastal Georgia 1999-2002: U.S. Geological Survey Scientific Investigations Report 2005-5124, 98 p.

Georgia Environmental Protection Division, 2003, Interim strategy for permitting Lower Floridan withdrawals in coastal Georgia: Memorandum issued January 28, 2003, Nolton Johnson, Chief, EPD Water Resources Branch.

Halford, K.J., 2006, Documentation of a spreadsheet for timeseries analysis and drawdown estimation: U.S. Geological Survey Scientific Investigations Report 2006-5024, 38 p.

Hantush, M.S., 1960, Modification of the theory of leaky aquifers: Journal of Geophysical Resources, v. 65, p. 3713-3725.

Hantush, M.S., and Jacob, C.E., 1955, Non-steady flow in an infinite leaky aquifer: Transactions of the American Geophysical Union, v. 36, p. 95-100.

McCollum, M.J., and Counts, H.B., 1964, Relation of saltwater encroachment to the major aquifer zones Savannah area, Georgia and South Carolina: U.S. Geological Survey Water-Supply Paper 1613-D, 26 p.

Miller, J.A., 1986, Hydrogeologic framework of the Floridan aquifer system in Florida and in parts of Georgia, Alabama, and South Carolina: U.S. Geological Survey Professional Paper 1403-B, $91 \mathrm{p}$.

Pandit, N.S., and Miner, R.F., 1986, Interpretation of slug test data: Ground Water, v. 24, p. 743-749.

Theis, C.V., 1935, The relation between the lowering of the piezometric surface and the rate and duration of discharge of a well using groundwater storage: Transactions of the American Geophysical Union, v. 16, p. 519-524. 
Manuscript approved on March 23, 2010

For more information about this publication, contact: USGS Georgia Water Science Center

3039 Amwiler Road

Atlanta, GA 30360

telephone: 770-903-9100

http://ga.water.usgs.gov/

Edited by Kay E. Hedrick

Layout by Caryl J. Wipperfurth 


\section{趈}

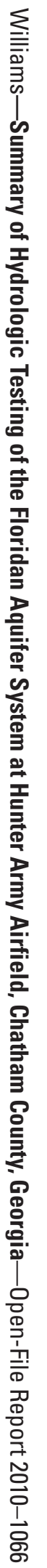

